$10-1-1988$

\title{
Is "Internal Consistency" Foolish?: Reflections on an Emerging Commerce Clause Restraint on State Taxation
}

Walter Hellerstein

University of Georgia School of Law, wallyh@uga.edu

p bepress

\section{Repository Citation}

Walter Hellerstein, Is "Internal Consistency" Foolish?: Reflections on an Emerging Commerce Clause Restraint on State Taxation (1988),

Available at: https://digitalcommons.law.uga.edu/fac_artchop/313

This Article is brought to you for free and open access by the Faculty Scholarship at Digital Commons @ University of Georgia School of Law. It has been accepted for inclusion in Scholarly Works by an authorized administrator of Digital Commons @ University of Georgia School of Law. Please share how you have benefited from this access For more information, please contact tstriepe@uga.edu. 


\title{
IS "INTERNAL CONSISTENCY” FOOLISH?: REFLECTIONS ON AN EMERGING COMMERCE CLAUSE RESTRAINT ON STATE TAXATION
}

\author{
Walter Hellerstein*
}

Before 1983, the Supreme Court had never uttered the phrase "internal consistency" in a state tax opinion. ${ }^{1}$ Since 1983, however, the Court has invoked the principle of "internal consistency" on four separate occasions in adjudicating the validity of state taxes under the commerce clause. ${ }^{2}$ Indeed, by 1987 , the Court could refer almost casually to the "internal consistency" criterion as "the test ... we have applied in other contexts." 3 The Court's talk of "internal consistency" cannot be dismissed as mere rhetoric. Three of the four taxes that have been put to the "internal consistency" test have flunked it; ${ }^{4}$ cases approving taxes that, in retrospect, would have failed the test have been overruled; ${ }^{5}$ and the test has cast a constitutional shadow over many other taxes. ${ }^{6}$ In the eyes of some members of the Court, moreover, general application of the "internal consistency" doctrine as a tool of commerce clause analysis is "an entirely novel enterprise" 7 that would "revolutionize the law of state taxation."

Whatever role "internal consistency" may come to play in the Court's commerce clause jurisprudence, it has already emerged as a doctrine that warrants our attention. This article traces the develop-

* Professor of Law, University of Georgia; A.B., Harvard, 1967; J.D., University of Chicago, 1970.-Ed. I am deeply indebted to Donald Regan for his detailed and illuminating critique of an earlier draft of this article; I am grateful as well to Milner Ball, Andrew Frey, Paul Kurtz, James Smith, Michael Wells, and Prentiss Willson, Jr., for their helpful comments.

1. The assertion is based on a LEXIS search of Supreme Court opinions for the phrase "internal consistency."

2. American Trucking Assns. v. Scheiner, 107 S. Ct. 2829, 2840 (1987); Tyler Pipe Indus. v. Washington Dept. of Revenue, 107 S. Ct. 2810, 2820 (1987); Armco, Inc. v. Hardesty, 467 U.S. 638, $644-45$ (1984); Container Corp. of Am. v. Franchise Tax Bd., 463 U.S. 159, 169 (1983).

3. Scheiner, $107 \mathrm{~S}$. Ct. at 2840.

4. Scheiner, 107 S. Ct. 2829; Tyler Pipe, 107 S. Ct. 2810; Armco, 467 U.S. 638.

5. See Scheiner, 107 S. Ct. at 2845-47 (overruling Capitol Greyhound Lines v. Brice, 339 U.S. 542 (1950); Aero Mayflower Transit Co. v. Board of R.R. Commrs., 332 U.S. 495 (1947); Aero Mayflower Transit Co. v. Georgia Pub. Serv. Commn., 295 U.S. 285 (1935)); Tyler Pipe, 107 S. Ct. at 2820 (overruling General Motors Corp. v. Washington, 377 U.S. 436 (1964)).

6. See text at notes 86-136 infra.

7. Scheiner, $107 \mathrm{~S}$. Ct. at 2850 (O'Connor, J., dissenting).

8. Tyler Pipe, 107 S. Ct. at 2825 (Scalia, J., dissenting). 
ment of the doctrine, explores its implications, and considers its defensibility as a limitation on state taxing power. The article suggests that the results the Court reaches under the "internal consistency" doctrine could be reached by rigorous application of a more familiar commerce clause principle - one to which the Court has been less than faithful.

\section{The DeVelopMENT OF THE "INTERNAL CONSISTENCY" DOCTRINE}

\section{A. Container Corporation of America v. Franchise Tax Board}

The Supreme Court first suggested that the principle of "internal consistency" constrained state taxing power in Container Corporation of America v. Franchise Tax Board. ${ }^{9}$ In discussing the constitutional limitations on the states' power to tax the income of a multistate business, the Court observed that the due process and commerce clauses require the states to be "fair" 10 in applying apportionment formulas to determine how much of the enterprise's income they may tax. The Court then declared: "The first, and . . . obvious, component of fairness in an apportionment formula is what might be called internal consistency - that is, the formula must be such that, if applied by every jurisdiction, it would result in no more than all of the unitary business' income being taxed."11

Read in context, the Court's statement was unexceptional. The Court has long interpreted the commerce and due process clauses as requiring that taxes be fairly apportioned to the taxpayer's activities in the taxing state. ${ }^{12}$ The fair apportionment requirement serves the function, among others, of implementing the commerce clause prohibition against multiple taxation of interstate commerce. ${ }^{13}$ If a tax is

9. 463 U.S. 159 (1983).

10. 463 U.S. at 169.

11. 463 U.S. at 169. Wholly apart from the question of the intrinsic fairness of an apportionment formula, a formula, though "internally consistent," may be unfair to a particular multistate taxpayer because it effectively taxes extraterritorial values. In Container, the Court characterized this second aspect of the fairness of an apportionment formula as the requirement of "external consistency - the factor or factors used in the apportionment formula must actually reflect a reasonable sense of how income is generated." 463 U.S. at 169.

12. See, e.g., Pullman's Palace Car Co. v. Pennsylvania, 141 U.S. 18, 26 (1891) (commerce clause); Union Tank Line Co. v. Wright, 249 U.S. 275, 281-83 (1919) (due process clause).

13. The multiple taxation doctrine forbids the states from imposing taxes that subject interstate commerce to a risk of multiple taxation not borne by local commerce. See Western Live Stock v. Bureau of Revenue, 303 U.S. 250, 255-56 (1938); J. HeLlERSTEIN \& W. HELLERSTEIN, STATE AND Local TAXATION 219-21 (5th ed. 1988); text at notes 149-72 infra. As Justice Rutledge articulated the doctrine in his concurring opinion in International Harvester Co. v. Department of Treasury, 322 U.S. 340, 358 (1944):

[T] he state may not impose certain taxes on interstate commerce, its incidents or instrumentalities, which are no more in amount or burden than it places on its local business, not because this of itself is discriminatory, cumulative or special or would violate due process, 
fairly apportioned to a taxpayer's activities in the state, there is no risk, at least in principle, that it will violate the multiple taxation doctrine by subjecting interstate commerce to a multiple tax burden not borne by local commerce.

Despite this general rule against multiple taxation, the Court has been quite tolerant in permitting the states to adopt apportionment formulas of their own choosing, even though the adoption of varying formulas by different states may in fact subject the interstate business to multiple taxation. ${ }^{14}$ So long as a state's formula is intrinsically fair, it is not constitutionally infirm merely because the adoption by a sister state of another intrinsically fair formula could create "some overlap"15 in taxation. The explanation for this exception to the commerce clause prohibition against multiple taxation lies in the Court's inability to determine which of the two competing formulas is "at fault in a constitutional sense"16 without prescribing uniform rules of apportionment among the states. The Court recognized that "the legislative power granted to Congress by the Commerce Clause of the Constitution would amply justify the enactment of legislation requiring all States to adhere to uniform rules for the division of income."17 But the Court has declined to undertake that task itself because it believes that it is neither institutionally equipped nor constitutionally authorized to do so.

The leeway the Court has accorded the states to design their own apportionment formulas, however, does not extend to formulas that, if adopted generally, will inevitably subject a multistate enterprise to multiple taxation. A formula ceases to be intrinsically fair when, if applied across all taxing states, it subjects a multistate enterprise to taxation of more than $100 \%$ of its tax base. ${ }^{18}$ This is because the doctrine of intrinsic fairness requires equity to the taxpayer whose tax base happens to be taxable in part by several states rather than in

but because other states also may have the right constitutionally, apart from the commerce clause, to tax the same thing and either the actuality or the risk of their doing so makes the total burden cumulative, discriminatory or special.

14. See Moorman Mfg. Co. v. Bair, 437 U.S. 267 (1978); Hellerstein, Commerce Clause Restraints on State Taxation: Purposeful Economic Protectionism and Beyond, 85 Mich. L. REV. 758, 763-66 (1987).

15. Moorman, 437 U.S. at 277.

16. 437 U.S. at 277.

17. 437 U.S. at 280.

18. This assumes, of course, that the intrastate business is subject to a tax on only $100 \%$ of its tax base. The unfaimess of formulas that inevitably tax the interstate business on more than $100 \%$ of its tax base is that they expose the interstate business to greater tax burdens than those borne by its intrastate competitor. $\mathrm{A}$ tax that subjected every business, interstate and intrastate alike, to an exaction on 150 or $200 \%$ of its appropriate tax base would not be intrinsically unfair, just somewhat bizarre. 
whole by a single state. Thus, for taxes to be intrinsically fair, the sum of the taxes derived from the parts may not exceed the taxes derived from the whole. Adventitious multiple taxation arising from the interaction of two inconsistent, but intrinsically fair, apportionment formulas may be the price we pay for federalism. Predictable multiple taxation arising from the generalized application of a single, intrinsically unfair, apportionment formula is a price we need not pay.

The Court's reference to "internal consistency" in Container appeared simply to remind us of this point. In fact, the Court made no further reference to the "internal consistency" criterion in its opinion, which was largely devoted to its analysis sustaining the application of California's widely accepted (and "internally consistent") three-factor apportionment formula to the taxpayer's worldwide combined income. ${ }^{19}$ One would have been prescient indeed to detect the birth of a new principle of commerce clause jurisprudence in the Court's brief description of an "obvious[] component of fairness in an apportionment formula." 20

\section{B. Armco, Inc. v. Hardesty}

Less than a year after Container, the Court attributed broader significance to the "internal consistency" doctrine in Armco, Inc. v. Hardesty. ${ }^{21}$ In Armco, the Court considered a claim of state tax discrimination under West Virginia's business and occupation (B \& $O$ ) tax. ${ }^{22}$ The $\mathrm{B} \& \mathrm{O}$ tax was a broad-based excise upon the privilege of engaging in most business activity in the state, including manufacturing and wholesaling. The tax was measured by gross business receipts. In general, if a taxpayer engaged in two different business activities, it paid a tax upon the privilege of engaging in each activity. A "multiple activities" exemption, however, relieved manufacturers subject to the manufacturing tax from liability for the wholesaling tax. The manufacturing tax was imposed at a higher rate than the wholesaling tax.

19. The most widely accepted formula for apportioning the income of a multijurisdictional business among the states employs three factors: real and tangible personal property, payroll, and sales. By averaging the ratios of the taxpayer's property, payroll, and sales within the state to its property, payroll, and sales throughout the business, the formula yields a fraction that can be applied to the taxpayer's net income to determine the portion taxable by the state. In Container Corp. of Am. v. Franchise Tax Bd., 463 U.S. 159 (1983), the Court described the three-factor formula as "something of a benchmark against which other apportionment formulas are judged." 463 U.S. at 170. See generally Hellerstein, State Income Taxation of Multijurisdictional Corporations: Reflections on Mobil, Exxon, and H.R. 5076, 79 Mich. L. REv. 113 (1980) [hereinafter Hellerstein, State Income Taxation].

20. Container, 463 U.S. at 169.

21. 467 U.S. 638 (1984).

22. 1971 W. Va. Acts 169 (repealed effective July 1, 1987). See Armco, 467 U.S. at 640 n.2. 
Armco, an Ohio manufacturer engaged in wholesaling in West Virginia, charged that the levy discriminated against interstate commerce because it taxed out-of-state manufacturers who sold at wholesale in the state, while exempting in-state manufacturers who sold at wholesale in the state. The Supreme Court agreed that the tax on its face discriminated against interstate commerce. ${ }^{23}$ The existence of a higher B \& $\mathrm{O}$ tax on in-state manufacturers did not cure the discrimination because the manufacturing tax could not be viewed as substantially equivalent to the wholesaling tax. ${ }^{24}$ Furthermore, and most importantly from the standpoint of the present inquiry, the Court rejected the state's contention that Armco had "to prove actual discriminatory impact on it by pointing to a State that imposes a manufacturing tax that results in a total burden higher than that imposed on Armco's competitors in West Virginia."25

This is not the test. In Container ... the Court noted that a tax must have "what might be called internal consistency — that is the [tax] must be such that, if applied by every jurisdiction," there would be no impermissible interference with free trade. In that case, the Court was discussing the requirement that a tax be fairly apportioned to reflect the business conducted in the State. A similar rule applies where the allegation is that a tax on its face discriminates against interstate commerce. A tax that unfairly apportions income from other States is a form of discrimination against interstate commerce. ... Any other rule would mean that the constitutionality of West Virginia's tax laws would depend on the shifting complexities of the tax codes of 49 other States, and that the validity of the taxes imposed on each taxpayer would depend on the particular other States in which it operated.26

West Virginia's tax plainly failed the "internal consistency" test. If every state imposed a tax like West Virginia's, the enterprise that manufactured in one state and wholesaled in another would pay a manufacturing tax to the state of manufacture and a wholesaling tax to the state of sale. Due to the levy's "multiple activities" exemption, however, the wholly intrastate manufacturer/wholesaler would pay a tax only on its manufacturing activity. Hence, the scheme would place the interstate manufacturer/wholesaler at a competitive disadvantage to the intrastate manufacturer/wholesaler by saddling the former with a multiple tax burden not borne by the latter and would thus

23. Armco, 467 U.S. at 642.

24. 467 U.S. at 642-43. See generally Hellerstein, Complementary Taxes as a Defense to Unconstitutional State Tax Discrimination, 39 TAX LAw. 405 (1986) [hereinafter Hellerstein, Complementary Taxes].

25. Armco, 467 U.S. at 644.

26. 467 U.S. at $644-45$ (citation omitted). 
create an "impermissible interference with free trade."27

The Court's extension of the "internal consistency" test to questions beyond the intrinsic fairness of a state's apportionment formula did not escape the attention of Justice Rehnquist. He vigorously objected to the Court's focus on hypothetical tax burdens borne by the interstate business, observing that the Court's prior decisions indicated "that when considering whether a tax is discriminatory, "equality for the purposes of competition and the flow of commerce is measured in dollars and cents, not legal abstractions." "28 Armco in fact had paid no manufacturing tax to Ohio, so there was no actual discrimination in the case. The Court, according to Justice Rehnquist, "sidestepped" this fact by

borrowing a concept employed in our net income tax cases. Under that line of cases a state tax must have an internal consistency that takes into consideration the impact on interstate commerce if other jurisdictions employed the same tax. It is perfectly proper to examine a State's net income tax system for hypothetical burdens on interstate commerce. Nevertheless, that form of analysis is irrelevant to examining the validity of a gross receipts tax system based on manufacturing or wholesale transactions. Where a State's taxes are linked exactly to the activities taxed, it should be unnecessary to examine a hypothetical taxing scheme to see if interstate commerce would be unduly burdened. ${ }^{29}$

Justice Rehnquist would thus have sustained West Virginia's B \& O tax, despite its internal inconsistency, because of his view that "internal consistency" analysis should play no role outside the specific context in which it was first invoked.

\section{Tyler Pipe Industries v. Washington Department of Revenue}

Three years after addressing the challenge to West Virginia's B \& O tax in Armco, the Court revisited the "internal consistency" doctrine in addressing a similar challenge to Washington's B \& $\mathrm{O}$ tax in Tyler Pipe Industries v. Washington Department of Revenue. ${ }^{30}$ Like West Virginia, Washington imposed its B \& O tax on gross receipts from various business activities carried on in the state, including manufacturing and wholesaling. Like West Virginia, Washington had a "multiple activities" exemption, which assured that taxpayers engaged in both manufacturing and wholesaling in the state would pay tax on only one activity. But, instead of exempting local manufacturer/

27. 467 U.S. at 644.

28. 467 U.S. at 647 (Rehnquist, J., dissenting) (quoting Halliburton Oil Well Cementing Co. v. Reily, 373 U.S. 64, 70 (1963)).

29. 467 U.S. at 648 (citation omitted).

30. 107 S. Ct. 2810 (1987). 
wholesalers from the state's wholesaling tax, as West Virginia had done, Washington exempted them from the state's manufacturing tax. In so doing, Washington avoided the particular problem of facial discrimination the Court had identified in Armco. Out-of-state manufacturers who made wholesale sales in Washington would pay the same tax on their wholesaling activities as their Washington-based competitors who manufactured and wholesaled their products in the state. ${ }^{31}$

In the Court's view, however, the fact that both out-of-state and local manufacturers paid the same wholesaling tax under Washington's B \& O tax did not cure the constitutional defect in Washington's tax. Judged by the standard of "internal consistency," Washington's levy was as constitutionally infirm as West Virginia's. Just as the interstate manufacturer/wholesaler in Armco was put at a competitive disadvantage to the intrastate manufacturer/wholesaler on the assumption that every state had adopted West Virginia's taxing scheme, so the same disadvantage would exist in Tyler Pipe on the assumption that every state had adopted Washington's taxing scheme. In each instance, the interstate manufacturer/wholesaler would pay both a manufacturing tax to the state of manufacture and a wholesaling tax to the state of sale, whereas the intrastate manufacturer/wholesaler would pay but one tax — a manufacturing tax under West Virginia's statute or a wholesaling tax under Washington's. In short, the Court's conclusion that Washington's taxing scheme was the "practical equivalent" 32 of West Virginia's, from the standpoint of "internal consistency," was inescapable. ${ }^{33}$

31. While avoiding facial discrimination against the out-of-state manufacturer making instate sales, Washington's scheme introduced a different form of facial discrimination against the local manufacturer making out-of-state sales. Local manufacturers making out-of-state sales paid a manufacturing tax whereas local manufacturers making in-state sales did not. Although the discrimination arguably disappeared if one considered that local manufacturers making instate sales paid a tax on their in-state sales activity equal to the tax that local manufacturers making out-of-state sales paid on their local manufacturing activity, a similar point was made, and rejected, in Armco with respect to the manufacturing tax paid by local manufacturer/wholesalers. See text at note 24 supra; Tyler Pipe, $107 \mathrm{~S}$. Ct. at 2816-19.

32. $107 \mathrm{~S}$. Ct. at 2817.

33. Even though it struck down Washington's B \& O tax as applied to interstate manufacturer/wholesalers, the Court in Tyler Pipe did suggest two alternatives for curing the constitutional defects in the statutory scheme by "eliminating exposure to the burden of a multiple tax on manufacturing and wholesaling." $107 \mathrm{~S}$. Ct. at 2819 . First, the state could provide a credit against Washington manufacturing tax liability for wholesale taxes paid by Washington manufacturers to any state, $107 \mathrm{~S}$. Ct. at 2819-20, and a credit against Washington wholesale tax liability for manufacturing taxes paid by out-of-state manufacturers to other states. $107 \mathrm{~S}$. Ct. at 2821. The credit would effectively leave the intrastate manufacturer/wholesaler in the same position it enjoyed under Washington's existing tax: it would receive a credit against its manufacturing tax liability for the wholesale taxes it paid, which has the same effect as an exemption from manufacturing tax liability because the manufacturing and wholesaling taxes were imposed at the same rates. At the same time, the credit would guarantee that the Washington manufacturer selling in other states paid only a single tax - a wholesale tax to the state of sale, if the state of 
The Court's reaffirmance of its commitment to the "internal consistency" principle drew an impassioned dissent - this time from Justice Scalia, ${ }^{34}$ who was not on the Court when Container and Armco were decided. Justice Scalia took the Court to task for its application of an "internal consistency" principle that was "nowhere to be found in the Constitution." 35 He chided the Court for overruling "a rather lengthy list of prior decisions" 36 in applying the "internal consistency" test to the case before it. And, while characterizing as "dictum"37 Armco's extension of the "internal consistency" principle to questions other than fair apportionment, Justice Scalia declared that if one nevertheless "insists on viewing it as holding, and thus as conflicting with decades of precedents upholding internally inconsistent state taxes ... Armco rather than those numerous other precedents ought to be overruled."38

Justice Scalia's quarrel with the Court over its application of the "internal consistency" principle, however, was based more on considerations of constitutional policy than on any abstract commitment to stare decisis. Scalia was willing to accept application of the principle in the apportionment context where "an inconsistent ... scheme could

sale imposed such a tax, or a manufacturing tax to Washington if it did not. The credit would likewise guarantee that the out-of-state manufacturer selling in Washington would pay only a single tax - a manufacturing tax to the state of manufacture, if the state of manufacture imposed such a tax, and a wholesale tax to Washington if it did not. The second alternative suggested by the Court was simply to repeal the manufacturing tax. $107 \mathrm{~S}$. Ct. at 2821.

In apparent response to the Court's first suggestion, the Washington legislature enacted legislation providing credits against Washington B \& O tax liability for gross receipts taxes paid to other states. See WASH. Rev. CodE ANN. \$ 82.04.440 (Supp. 1988). Under the legislation, Washington manufacturers making out-of-state sales and out-of-state manufacturers making sales in Washington receive a credit against B \& $O$ tax liability for gross receipts taxes they pay to other states. This so-called "credit fix" was estimated to cost the state $\$ 42$ million. 1988 Daily Tax Report (BNA) No. 24 at H-9 (Feb. 5, 1988). The Washington Supreme Court limited the fiscal damage from the Court's opinion by holding that it should only apply prospectively and that refunds therefore were not required. National Can Corp. v. Washington Dept. of Revenue, 109 Wash. 2d 878, 749 P.2d 1286, appeal dismissed and cert. denied, 108 S. Ct. 2030 (1988).

It is worth noting that the second alternative suggested by the Court - repealing the manufacturing tax - would not protect the interstate business from the very burdens the Court identified in Tyler Pipe, even though it would solve the "internal consistency" problem. If half the states adopted taxes on manufacturing (without taxes on wholesaling) and half the states adopted taxes on wholesaling (without taxes on manufacturing) the interstate manufacturer/wholesaler would still suffer the competitive disadvantage of paying two taxes while its intrastate counterpart paid only one. For further discussion of and a suggested solution to this problem, see text accompanying notes 216-20 infra.

34. Justice Scalia was joined in this part of his dissent by Chief Justice Rehnquist. See $107 \mathrm{~S}$. Ct. at 2823.

35. 107 S. Ct. at 2824 (Scalia, J., dissenting).

36. 107 S. Ct. at 2824.

37. $107 \mathrm{~S}$. Ct. at 2824.

38. 107 S. Ct. at 2824. 
result in taxation of more than 100 percent of [a] firm's net income."39 But where a "tax is assessed not on unitary income but on discrete events such as sale, manufacture, and delivery, which can occur in a single State or in different States, that apportionment principle is not applicable; there is simply no unitary figure or event to apportion."40 Rather than expand Armco's holding to "revolutionize the law of state taxation," 41 Scalia would have adhered to "our long tradition of judging State taxes on their own terms" 42 and would not "strik[e] them down on the-basis of assumptions as to what other States might do."43

\section{American Trucking Associations v. Scheiner}

On the same day it rendered its decision in Tyler Pipe, the Court elaborated further on the "internal consistency" doctrine in American Trucking Associations v. Scheiner, ${ }^{44}$ which invalidated Pennsylvania's lump-sum annual taxes on the operation of trucks in the state. The taxes at issue were an axle tax ranging from $\$ 72$ to $\$ 180$ per truck and a $\$ 25$ identification marker fee. The truckers attacked these levies under the commerce clause on the ground, among others, that they imposed a multiple tax burden on interstate commerce. ${ }^{45}$ If Pennsylvania had the right to impose a flat tax on their operations, the truckers claimed, then so could every other state, and the cumulative consequences of such a regime would impose a crippling financial burden on interstate motor carriers. ${ }^{46}$ In addressing this contention, the Court returned again to the principle of "internal consistency" - "the test ... that we have applied in other contexts."47

Before putting the challenged exactions to the test, the Court ap-

\footnotetext{
39. 107 S. Ct. at 2824.

40. $107 \mathrm{~S}$. Ct. at $2824-25$.

41. $107 \mathrm{~S}$. Ct. at 2825.

42. 107 S. Ct. at 2826.

43. $107 \mathrm{~S}$. Ct. at 2826 (emphasis in original).

44. 107 S. Ct. 2829 (1987). In the interest of full disclosure, it should be noted that I served as counsel to the American Trucking Associations in the Scheiner case. The views expressed here, however, are my own and do not necessarily represent those of the American Trucking Associations.

45. The truckers' other principal argument was that the taxes discriminated against interstate commerce by imposing a substantially higher effective tax rate on trucks registered outside the state than on trucks registered in the state. Because flat taxes are not levied in proportion to the extent of a vehicle's use of a state's roads, they result in lower per mile costs for heavy users than for light users of the state's highways. Because the average Pennsylvania-registered truck used the state's roads more extensively than the average out-of-state truck, the lower effective tax rate inured to the benefit of the local trucker by comparison to his out-of-state counterpart.

46. Brief for American Trucking Associations at 35, American Trucking Assns. v. Scheiner, 107 S. Ct. 2829 (1987) (No. 86-357).

47. $107 \mathrm{~S}$. Ct. at 2840.
} 
plied the test to the registration fees and fuel consumption taxes that all states impose on the trucking industry. Although registration fees can be characterized as flat taxes imposed by every state, they nevertheless pass the "internal consistency" test because, as a result of reciprocity and apportionment provisions, ${ }^{48}$ they do not impose cumulative tax burdens upon the interstate carrier not borne by its intrastate competitor.

Under this test, even though the registration fee is assessed, as indeed it has been, by every jurisdiction, it causes no impermissible interference with free trade because every State respects the registration of every other State. Payment of one registration fee enables a carrier to operate a vehicle either locally or in the interstate market. Having paid one registration fee, a vehicle may pass among the States as freely as it may roam the State in which it is based; the Commerce Clause is not offended when state boundaries are economically irrelevant. 49

Motor fuel taxes imposed by Pennsylvania likewise passed the "internal consistency" test even though they were imposed by every jurisdiction. Because they are apportioned to mileage in Pennsylvania, they impose no greater burden on the interstate than on the intrastate carrier. Each pays the same amount "for traveling a certain distance that happens to be within Pennsylvania."so

But Pennsylvania's flat taxes for the use of its roads failed the "internal consistency" test. Payment of the flat taxes to Pennsylvania, unlike payment of registration fees, provided no immunity from payment of similar taxes imposed by other states. Nor were flat taxes, unlike motor fuel taxes, apportioned to some neutral factor like extent of road use, which made state lines irrelevant. While registration fees and motor fuel taxes could thus be replicated by every state without putting the interstate carrier at a competitive disadvantage, the same could not be said of unapportioned flat taxes. "If each State imposed flat taxes for the privilege of making commercial entrances into its territory, there is no conceivable doubt that commerce among the States would be deterred."51

48. Reciprocity agreements among the states grant owners of vehicles paying registration fees to one state the privilege of operating over the highways of other states. In addition, many states participate in the International Registration Plan under which registration fees paid for a truck are apportioned among member states in accordance with the number of miles driven by the truck in each state. See Scheiner, $107 \mathrm{~S}$. Ct. at 2834.

49. $107 \mathrm{~S}$. Ct. at 2840.

50. $107 \mathrm{~S}$. Ct. at 2840 .

51. $107 \mathrm{~S}$. Ct. at 2840. The Court in Scheiner reaffirmed its view expressed in Armco and Tyler Pipe that the application of the "internal consistency" test does not depend on whether states other than the taxing state have in fact imposed similar taxes so as to place an actual burden on interstate commerce. $107 \mathrm{~S}$. Ct. at 2841 . Yet it went on to note that other states had in fact adopted flat taxes so that the threat to free trade was in no sense hypothetical. Moreover, some states had adopted retaliatory taxes assessed on motor vehicles based in Pennsylvania or 
Dissenting from the Court's opinion in Scheiner, Justice Scalia reiterated his view expressed in Tyler Pipe that the "internal consistency" test was neither grounded in the Constitution nor compelled by the Court's precedents. ${ }^{52}$ This time Justice Scalia's sentiments were shared not only by Chief Justice Rehnquist, who joined his dissenting opinion in Tyler Pipe, ${ }^{53}$ but also, in a separate dissenting opinion, by Justices O'Connor and Powell.54 In her dissenting opinion, Justice O'Connor refused to "read Armco as establishing a grandiose version of the 'internal consistency test' as the constitutional measure of all state taxes under the Commerce Clause." 55 She read Armco as establishing at most "that a tax that is facially discriminatory is unconstitutional if it is not internally consistent," "56 and would in no event extend the "internal consistency" principle to nondiscriminatory taxes. "Creating an 'internal consistency' rule of general application," concluded Justice O'Connor, was "an entirely novel enterprise that the Court undertakes for the first time in this case." The Court, in her judgment, offered "no reason why such a rule is necessary or desirable." 57

\section{The IMPLICATIONS OF THE "INTERNAL CONSISTENCY” DOCTRINE}

The Court's apparent embrace of the "internal consistency" doctrine has consequences far beyond its immediate impact on the taxes at issue in Armco, Tyler Pipe, and Scheiner. In the course of its opinions in these cases, the Court disapproved a number of precedents sustaining taxes that fail the "internal consistency" test. Moreover, the Court's adoption of "internal consistency" as a general principle of commerce clause adjudication places many other state tax levies under a constitutional cloud.

\section{A. The Precedents Disapproved by the Court}

\section{General Motors Corporation v. Washington}

Twenty-three years before it struck down Washington's B \& O tax

other flat tax states, and these levies threatened to "divide and disrupt the market for interstate transportation services." $107 \mathrm{~S}$. Ct. at 2841.

52. $107 \mathrm{~S}$. Ct. at 2851 (Scalia, J., dissenting).

53. See text at note 34 supro.

54. $107 \mathrm{~S}$. Ct. at 2848-51 (O'Connor, J., dissenting). Chief Justice Rehnquist also joined this opinion.

55. $107 \mathrm{~S}$. Ct. at 2850.

56. 107 S. Ct. at 2850.

57. $107 \mathrm{~S}$. Ct. at 2850 . 
in Tyler Pipe, the Supreme Court sustained the application of the tax to an out-of-state manufacturer making wholesale sales in the state. In General Motors Corp. v. Washington, ${ }^{58}$ the Court held that neither the commerce clause nor the due process clause was offended by the state's levy of a tax on General Motors' gross receipts from sales to Washington dealers. The Court's opinion made no reference to the doctrine of "internal consistency," which would remain in gestation for another two decades. Interestingly enough, however, Justice Goldberg's dissent in General Motors articulated such a doctrine in substance.

Justice Goldberg observed that Washington's B \& O tax had at one time exempted Washington manufacturer/wholesalers from the state's wholesaling tax under its "multiple activities" exemption. Anticipating the Supreme Court's decision in Armco, the Washington Supreme Court struck down the tax in 1948 on the ground that it discriminated against interstate commerce by taxing wholesale sales by out-of-state manufacturers to Washington purchasers, while exempting wholesale sales by Washington manufacturers to Washington purchasers. ${ }^{59}$ Washington thereupon amended its "multiple activities" exemption to provide that local manufacturer/wholesalers would be subject to the wholesaling tax but exempt from the manufacturing tax. In Justice Goldberg's judgment, this cosmetic change in the Washington scheme "would seem to have essentially the same economic effect on interstate sales but has the advantage of appearing nondiscriminatory."60 As Justice Goldberg explained,

[e]ven under the amended "multiple activities" exemption, ... an out-ofstate firm manufacturing goods in a State having the same taxation provisions as does Washington would be subjected to two taxes on interstate sales to Washington customers. The firm would pay the producing State a local manufacturing tax measured by sales receipts and would also pay Washington a tax on wholesale sales to Washington residents. Under such taxation programs, if an out-of-state manufacturer competes with a Washington manufacturer, the out-of-state manufacturer may be seriously disadvantaged by the duplicative taxation. ${ }^{61}$

The Court's response to Justice Golberg's commerce clause objection was that the taxpayer had failed to "demonstrat[e] what definite burden, in a constitutional sense" 62 any other states' taxes had imposed on the activities taxed by Washington. "In such cases," the

58. 377 U.S. 436 (1964).

59. Columbia Steel Co. v. State, 30 Wash. 2d 658, 664, 192 P.2d 976, 979 (1948).

60. General Motors, 377 U.S. at 460 (Goldberg, J., dissenting).

61. 377 U.S. at 460 .

62. 377 U.S. at 449. 
Court declared, "we have refrained from passing on the question of 'multiple taxation." "63 In other words, because the taxpayer had not shown that Washington's tax, considered in conjunction with other states' taxes, had in fact subjected the interstate manufacturer/wholesaler to a tax burden on its manufacturing-wholesaling activities greater than that imposed on its intrastate counterpart's manufacturing-wholesaling activities, the taxpayer had no constitutionally cognizable claim.

Justice Goldberg's dissent in General Motors was rehabilitated in Tyler Pipe. The Court in Armco had relied on the dissent for its condemnation of Washington's earlier taxing scheme, which, as noted above, ${ }^{64}$ was identical to West Virginia's. ${ }^{65}$ In Tyler Pipe, the Court came full circle and adopted Justice Goldberg's views in their entirety. It declared that its reliance on Justice Golberg's opinion in Armco compelled it to "agree with Justice Goldberg's conclusion that the exemption before us is the practical equivalent of the exemption that the Washington Supreme Court invalidated in 1948."66 To the extent that General Motors was inconsistent. with this conclusion, it was overruled.67

\section{The "Flat Tax" Precedents}

In Scheiner, as in Armco and Tyler Pipe, there was little doubt that a straightforward application of the "internal consistency" principle to the taxes at issue would brand them as unconstitutional. Indeed, Justice Scalia's dissent in Tyler Pipe, while castigating the Court for its adoption of the "internal consistency" test, nevertheless conceded that "[i]t is clear ... that ... any unapportioned flat tax on multistate activities, such as the axle tax or marker fee at issue in Scheiner"68 would fail the test. The real problem the Court confronted in Scheiner, therefore, was not whether flat taxes for highway use could survive commerce clause scrutiny under the "internal consistency" criterion. Rather, it was how to deal with the fact that the Court had previously considered and squarely rejected commerce clause attacks on such taxes.

In a series of cases decided between 1935 and 1950, the Court upheld flat taxes for highway use in the face of the contention that such

63. 377 U.S. at 449.

64. See text at note 59 supra.

65. Armco, Inc. v. Hardesty, 467 U.S. 638, 642 (1984).

66. Tyler Pipe Indus. v. Washington Dept. of Revenue, 107 S. Ct. 2810, 2817 (1987).

67. $107 \mathrm{~S}$. Ct. at 2820.

68. 107 S. Ct. at 2824 (Scalia J., dissenting). 
taxes violated the commerce clause because they were not proportional to the vehicle's use of the roads in the state. ${ }^{69}$ In sustaining these taxes, the Court reasoned that taxes precisely calibrated to wear and tear of the highways by a particular vehicle would not be administratively feasible; that the taxes at issue were imposed for the privilege of using the highways rather than their actual use, and out-of-state vehicle owners could not complain if they failed to avail themselves of the opportunity to use the roads as much as in-state vehicle owners; and that the taxes at issue were not burdensome to interstate carriers. ${ }^{70}$ If these precedents were good law, then the "internal consistency" principle - at least in its broad configuration - was not.

Forced to choose between its old and its new doctrine, the Court chose the latter. The Court observed that the holdings of many of the earlier flat highway tax cases turned on the fact that the taxes were exacted in consideration for the "privilege" of using the state's highways, a taxable "local" subject, rather than the privilege of doing interstate business. ${ }^{71}$ In recent years, however, the Court has taken considerable pains to discredit the privilege doctrine and to eliminate it from commerce clause analysis. ${ }^{72}$ Thus, the Court concluded that the precedents upholding flat taxes can no longer support the broad proposition ... that every flat tax for the privilege of using a State's highways must be upheld even if it has a clearly discriminatory effect on commerce by reason of that commerce's interstate character. ${ }^{73}$

Despite the Court's disapproval of its flat tax precedents, the Court did not completely jettison them. The Court recognized, as it had in its earlier decisions, that the commerce clause did not prevent the states from employing flat taxes when they are the only practicable means of collecting revenue from highway users and when the use of

69. See Aero Mayflower Transit Co. v. Georgia Pub. Serv. Commn., 295 U.S. 285 (1935) (Aero Mayflower I); Aero Mayflower Transit Co. v. Board of R.R. Commrs., 332 U.S. 495 (1947) (Aero Mayflower II); Capitol Greyhound Lines v. Brice, 339 U.S. 542 (1950).

70. See Aero Mayflower I, 295 U.S. at 289; Aero Mayflower II, 332 U.S. at 503-04, 506 n.19; Capitol Greyhound Lines, 339 U.S. at 544, 546-47. Perhaps because the Court viewed the highway tax cases as sui generis, it never felt compelled in these cases to reconcile the results with its long line of precedents invalidating flat fee drummers' license taxes as burdens on interstate commerce. See, e.g., Nippert v. City of Richmond, 327 U.S. 416 (1946); Best \& Co. v. Maxwell, 311 U.S. 454 (1940); Robbins v. Shelby County Taxing Dist., 120 U.S. 489 (1887).

71. Scheiner, 107 S. Ct. at $2845-46$.

72. See Commonwealth Edison Co. v. Montana, 453 U.S. 609, 614-17 (1981) (overruling Heisler v. Thomas Colliery Co., 260 U.S. 245 (1922)); Department of Revenue v. Association of Washington Stevedoring Cos., 435 U.S. 734, 743-50 (1978) (overruling Joseph v. Carter \& Weekes Stevedoring Co., 330 U.S. 422 (1947) and Puget Sound Stevedoring Co. v. State Tax Commn., 302 U.S. 90 (1937)); Complete Auto Transit, Inc. v. Brady, 430 U.S. 274, 278-79 (1977) (overruling Spector Motor Serv. v. O'Connor, 340 U.S. 602 (1951)).

73. Scheiner, $107 \mathrm{~S}$. Ct. at 2847 . In so holding, the Court finally reconciled its doctrine regarding flat taxes on trucks with its doctrine regarding flat taxes on drummers. $107 \mathrm{~S}$. Ct. at 2840 n.16; see note 70 supra. 
more refined methods of taxation would impose genuine administrative burdens. ${ }^{74}$ Hence, the Court implicitly recognized that there are some limits to the "internal consistency" principle, even if Pennsylvania was in no position to invoke them. ${ }^{75}$

\section{Precedents Implicitly Disapproved by the Court}

While General Motors and the flat highway tax cases were the only precedents that the Court explicitly disparaged in its "internal consistency" opinions, other precedents may now be of questionable force in light of Armco, Tyler Pipe, and Scheiner. Insofar as it sustained the application of Washington's B \& O tax to an out-of-state manufacturer making wholesale sales in the state, Standard Pressed Steel Co. v. Department of Revenue ${ }^{76}$ would no longer be followed. ${ }^{77}$ Nor, presumably, would the Court's numerous decisions sustaining flat license taxes on interstate enterprises. ${ }^{78}$ If every state imposed a flat license tax on the activity in question, the resulting multiple tax burden imposed on the multistate enterprise engaged in such activity would place it at an obvious disadvantage to its intrastate competitor in violation of the "internal consistency" doctrine.

Hinson v. Lott, ${ }^{79}$ as suggested by Justice Scalia, ${ }^{80}$ is another venerable precedent that has been undermined by the "internal consistency" principle. In Hinson, the Court considered an Alabama tax of fifty cents per gallon upon spirituous liquor dealers "introducing any such

74. 107 S. Ct. at 2847.

75. Pennsylvania routinely used mileage figures to determine motor carriers' fuel taxes and their registration fees (when such fees are figured on an apportioned basis). It likewise apportioned its corporate net income tax, imposed on interstate carriers on a mileage basis. Hence, under the facts of the case, the exception to the commerce clause bar against flat taxes for those justified by administrative necessity could not save Pennsylvania's levies, given the availability of administrative machinery "capable of taking into account at least the gross variations in cost per unit of highway usage between Pennsylvania-based and out-of-state carriers." $107 \mathrm{~S}$. Ct. at 2847.

76. 419 U.S. 560 (1975).

77. In Tyler Pipe, the Court referred to Standard Pressed Steel as a case that stood for the proposition, which was subsequently repudiated, that a taxpayer must "prove that specific interstate transactions were subjected to multiple taxation in order to advance a claim of discrimination." Tyler Pipe Indus. v. Washington Dept. of Revenue, 107 S. Ct. 2810, 2817 (1987). See generally Hellerstein, State Taxation of Interstate Business and the Supreme Court, 1974 Term: Standard Pressed Steel and Colonial Pipeline, 62 VA. L. REV. 149 (1976) [hereinafter Hellerstein, Interstate Business].

78. See, eg., City of Chicago v. Willett Co., 344 U.S. 574 (1953) (sustaining over commerce clause objections flat license taxes on "carters" as applied to "carters" engaged in interstate commerce); Wagner v. City of Covington, 251 U.S. 95 (1919) (sustaining over commerce clause objections $\$ 150$ license tax as applied to an interstate vendor of soft drinks); Browning v. City of Waycross, 233 U.S. 16 (1914) (sustaining over commerce clause objections \$25 occupation tax as applied to local agent of interstate vendor of lightning rods).

79. 75 U.S. (8 Wall.) 148 (1869).

80. Tyler Pipe, 107 S. Ct. at 2824 (Scalia, J., dissenting). 
liquors into the State for sale . ..."81 The Court acknowledged that "[i]f this section stood alone in the legislation of Alabama on the subject of taxing liquors," 82 it would discriminate against products of other states in violation of the commerce clause. ${ }^{83}$ The Court observed, however, that other sections of the statute imposed a tax of fifty cents per gallon upon whiskey and brands from fruits manufactured in the state. Viewed in light of this "complementary" tax, 84 the tax on out-of-state liquor was sustained because it was, in the Court's judgment, part of a scheme that imposed an equal tax on all liquor sold in the state. ${ }^{85}$

Under the "internal consistency" doctrine, however, the taxing scheme in Hinson would not pass muster. The tax on out-of-state liquor in that case was imposed upon the seller, while the tax on local liquor was imposed upon the manufacturer. If such taxing provisions were in force in every state, the manufacturer selling. liquor across state lines would pay a tax to the state where the liquor was distilled and to the state where it was sold, whereas the wholly local enterprise, selling all its liquor in the state where it was distilled, would pay only the tai on manufacture.

\section{B. The Impact of the "Internal Consistency" Doctrine on Existing State Tax Structures}

\section{Unapportioned Flat Taxes}

Far more important than the "internal consistency" doctrine's impact on individual Supreme Court precedents is its impact on existing state tax structures. Needless to say, flat highway taxes are now vulnerable to constitutional attack, a point that has not been lost on the trucking industry. ${ }^{86}$ More significantly, the imposition of any unap-

81. Hinson, 75 U.S. (8 Wall.) at 148 (quoting Act of Feb. 22, 1866, 1866 Ala. Acts) (emphasis omitted).

82. 75 U.S. at 150.

83. 75 U.S. at 152.

84. 75 U.S. at 153.

85. 75 U.S. at 153. See generally Hellerstein, Complementary Taxes, supra note 24.

86. The attack is being vigorously waged by the trucking industry. See American Trucking Assn. v. Gray, 108 S. Ct. 2 (Blackmun, Circuit Justice 1987) (granting injunction requiring Arkansas officials to establish escrow fund for tax payments pending challenge to state's flat highway tax); American Trucking Assns. v. Arkansas Highway and Transp. Dept., No. 85-101 (Mar. 14, 1988) Ark. St. Tax Rep. \{200-16 (declaring flat highway tax unconstitutional); Commonwealth Transp. Cabinet v. American Trucking Assns., 746 S.W.2d 65 (Ky. 1988) (declaring flat highway tax unconstitutional); Black Beauty Trucking, Inc. v. Indiana Dept. of State Revenue, No.49T05-8706-TA-00026 (Ind. Tax Ct. Jan. 7, 1988), reported in [Ind.] St. Tax Rep. (CCH) I] 200-715; George Transfer, Inc. v. Indiana State Dept. of Revenue, No. 49T05-8706-TA-00027 (Ind. Tax Ct. Jan. 7, 1988), reported in [Ind.] St. Tax Rep. (CCH) I 200-715 (declaring flat highway tax unconstitutional); American Trucking Assns. v. Indiana Dept. of State Revenue, 
portioned flat state or local tax on a multistate business would appear to be vulnerable to attack under the "internal consistency" doctrine, unless administrative considerations make "more finely calibrated" levies "impracticable." 87 This conclusion follows inexorably from a simple application of the "internal consistency" principle. If every state were to impose an unapportioned flat tax on business activities in which both intrastate and interstate enterprises engage, the interstate business would pay the tax in each state in which it did business, whereas its intrastate competitor would pay but a single tax in the state in which it did business. Because the tax is not apportioned to the activity carried on in the state, the interstate enterprise would bear a heavier tax burden than its intrastate competitor merely because it was engaged in interstate commerce - a paradigmatic "impermissible interference with free trade." 88

The implications of this conclusion are rather unsettling. Every state imposes initial fees and taxes on domestic and foreign corporations when first organizing or qualifying to do business in the state. ${ }^{89}$ Many of these levies are unapportioned flat taxes. 90 Under the "internal consistency" doctrine, such levies may not survive commerce clause scrutiny. If every state were to impose an unapportioned flat tax for the privilege of engaging in business activity in the state, ${ }^{91}$ the interstate enterprise would bear an additional tax burden simply because it was carrying on business across state lines and without regard

512 N.E.2d 920 (Ind. Tax Court 1987) (ordering escrow for tax payments pending challenge to flat highway tax); National Private Trucking Assn. v. Indiana Dept. of State Revenue, 512 N.E.2d 928 (Ind. Tax Court 1987) (ordering escrow for tax payments pending challenge to flat highway tax). American Trucking Assns. v. Conway, No. S-147-86W (Vt. Super. Ct. Feb. 11, 1988), reported in Vt. St. Tax Rep. (CCH) I 200-306 (declaring flat tax on trucks unconstitutional and ordering refund of escrowed taxes).

87. American Trucking Assns. v. Scheiner, 107 S. Ct. 2829, 2847 (1987). Justice Scalia explicitly recognized this point. See text at note 68 supra.

88. Armco, Inc. v. Hardesty, 467 U.S. 638, 644 (1984) quoted in text at note 26 supra; see Regan, The Supreme Court and State Protectionism: Making Sense of the Dormant Commerce Clause, 84 MICH. L. REV. 1091, 1186 (1986).

89. See 1 [All States] State Tax Guide (CCH) II 1-201 to 1-955 (Feb. 1988); All States Tax Guide (P-H) I 211-A. The levies discussed in this and the next paragraph are presumed to be imposed for revenue purposes under the state's taxing power, as distinguished from fees that are imposed for regulatory purposes under the state's police powers. See 2 [All States] State Tax Guide (CCH) II 30-000, at 3011-12 (Mar. 1988). Regulatory fees are discussed in the succeeding paragraphs. See text following note 96 infra.

90. See note 86 supra. Wholly apart from any "internal consistency" objection, many of these levies impose greater tax burdens on foreign than on domestic corporations, an apparent violation of the commerce, if not the equal protection, clause. See Metropolitan Life Ins. Co. v. Ward, 470 U.S. 869 (1985). But that is the subject of another article.

91. There is no longer a per se objection under the commerce clause to imposing a tax on the privilege of doing business in the state as applied to an enterprise engaged exclusively in interstate commerce. See Complete Auto Transit, Inc. v. Brady, 430 U.S. 274 (1977) (overruling Spector Motor Serv. v. O’Connor, 340 U.S. 602 (1951)). 
to whether it was carrying on more or less business in the state than its intrastate competitor. Conceivably, such levies could be defended on the ground of administrative necessity - that it would be impracticable to provide for their apportionment based on some neutral measure of the extent to which the enterprise has exploited the privilege of conducting business in the state. These arguments have a hollow ring, however, at least in the overwhelming majority of states that tax income, capital stock, or other bases, and provide, under constitutional compulsion, methods for apportioning the tax measure to the state..$^{92}$

Another broad category of exactions that the "internal consistency" doctrine places in constitutional jeopardy encompasses annual business license taxes imposed by states and localities for carrying on particular trades or occupations. ${ }^{93}$ Many of these are unapportioned flat taxes. ${ }^{94}$ The hypothetical replication of these taxes by every state under the "internal consistency" doctrine imposes a cumulative tax burden upon the multistate enterprise not borne by its intrastate competitor solely because the multistate business has chosen to do business in more than one state. For example, Alaska's twenty-five dollar annual business license tax, 95 if adopted by each of the other forty-nine states, would subject the enterprise doing business in fifty states to a $\$ 1250$ tax burden, compared to its local competitor's twenty-five dollar tax burden, even if the former's nationwide business was identical to the latter's in every respect except that it was conducted in fifty states instead of one. Although the assumption of identity between the interstate and intrastate business may be unrealistic, the implications

92. It may be argued, contrary to the assumption made at the outset of this paragraph, see note 89 supra, that organization, initiation, or business qualification fees should not be treated as true revenue measures because they are more accurately viewed as components of the states' regulatory regimes governing corporations. As noted below, however, see text at notes 97-105 infra, it is questionable whether this distinction would make a constitutional difference under "internal consistency" analysis, except in those cases in which it could be demonstrated that apportionment of the fees in question was administratively impracticable or that the fees in fact constituted user charges. See text at notes 104-11 infra. As a practical matter, however, there may be something to be said for a de minimis rule that removed modest corporate organization, initiation, or qualification fees from the "internal consistency" requirement. Unlike license fees, which are imposed annually and can be levied on a per store, per truck, or per location basis, these initial fees are imposed only once and on an enterprise-wide basis.

93. See 2 [All States] State Tax Guide (CCH) గी 30-201 to 30-955 (Mar. 1988).

94. See, e.g., ALA. CoDE $\S \S 40-12-1$ to -206 (1985 \& Supp. 1987); FLA. STAT. $\S \S 205.013-$ .1965 (1987); [Fla.] St. Tax Rep. (CCH) If 33-100; N.C. GEN. STAT. § 105-33 (1985). A number of these flat business license taxes are graduated according to the gross receipts of the business, with the fixed fee increasing with the receipts of the business, usually up to a statutory maximum above a certain level of receipts. See, e.g., LA. REV. STAT. ANN. $\$ \$ 47: 354$ to :357 (West Supp. 1988). Although one can argue that such levies are apportioned to the business done in the state, insofar as the statutory maximum is not exceeded, once the maximum is exceeded a graduated flat tax is indistinguishable from an ungraduated flat tax for analytical purposes.

95. Alaska Stat. $\$ 43.70 .030$ (1983). 
of "internal consistency" analysis are inescapable. ${ }^{96}$

A third category of unapportioned flat taxes that may be subject to constitutional attack under the "internal consistency" doctrine comprises the professional and similar licensing fees that are imposed by every state. Many of these fees are flat and unapportioned, and, for that reason, could be challenged under the "internal consistency" rationale set forth in the preceding paragraphs. One feature of these licensing fees, however, arguably insulates them from challenge under the "internal consistency" doctrine. In contrast to the exactions discussed above, which were presumed to be imposed for general revenue purposes pursuant to the state's taxing power, ${ }^{97}$ the levies considered here are presumed to be imposed for regulatory purposes pursuant to the state's police power. However thin that distinction may be in some cases, it is a distinction the law recognizes, ${ }^{98}$ and the question for present purposes is whether it is a distinction that makes a constitutional difference insofar as commerce clause (and "internal consistency") analysis is concerned.

The issue whether an exaction is a "tax" or a "fee" arises in a variety of contexts. Courts have had to determine whether charges by federal agencies are authorized fees for benefits granted ${ }^{99}$ or are in substance taxes that can be imposed only by Congress' exercise of its taxing power. ${ }^{100}$ They have had to determine whether levies are taxes subject to priority in bankruptcy proceedings or are fees not entitled to such priority. ${ }^{101}$ And they have had to determine whether exactions are taxes subject to states' constitutional requirements of uniformity and equality or are fees not subject to such requirements. ${ }^{102}$ There is no doubt in these cases, however, that the levy, if not an exercise of governmental tax power is nevertheless an exercise of governmental

96. Although the level of Alaska's tax might preclude, as a practical matter, any legal challenge to the levy. Compare CAL. REv. \& TAX CODE $§ 23151$ (West Supp. 1988), which imposes a minimum $\$ 300$ annual corporate franchise tax that will increase to $\$ 800$ by 1990 . Wholly apart from "internal consistency" analysis, one might argue that levies such as Alaska's and California's are inconsistent with the analysis in the cases invalidating flat taxes on drummers. See notes 70 \& 73 supra.

97. See note 89 supra.

98. See notes $99-102$ infra and accompanying text.

99. See 31 U.S.C. $\$ 9701$ (1982) (delegating to administrative agencies the authority to assess charges in situations where "a service or thing of value" is provided by the agency).

100. See Federal Power Commn. v. New England Power Co., 415 U.S. 345 (1974); National Cable Television Assn. v. United States, 415 U.S. 336 (1974).

101. See In re Jenny Lynn Mining Co., 780 F.2d 585, 588-89 (6th Cir. 1986); In re Lorber Indus., 675 F.2d 1062 (9th Cir. 1982).

102. See City of Fairmont v. Pitrolo Pontiac-Cadillac, 308 S.E.2d 527 (W. Va. 1983), cert. denied, 466 U.S. 958 (1984) ("fire service fee" constitutes ad valorem property tax); Newman v. City of Indianola, 232 N.W.2d 568 (Iowa 1975) (special assessment for local improvement does not constitute tax). 
regulatory power. Because the commerce clause applies to state regulation as well as to state taxation, the only question raised by the taxversus-fee issue in the present context is whether the "internal consistency" doctrine is limited in application to levies that are determined to be taxes.

Although the Court's formal criteria for evaluating commerce clause challenges to state regulations are not identical to its criteria for evaluating commerce clause challenges to state taxation, ${ }^{103}$ there is no reason to believe that a regulatory license fee would be immune from the "internal consistency" requirement merely because it constituted an exercise of the state's regulatory power rather than an exercise of the state's taxing power. Surely the evils that the "internal consistency" test was designed to combat are the same regardless of whether the unapportioned flat levy is an exercise of the tax power or the regulatory power. In each case, the licensee carrying on his trade in more than one jurisdiction bears a greater financial burden than his intrastate competitor merely because he is engaging in interstate commerce with the consequent interference with free trade among the states. Hence there does not appear to be any sound policy basis for distinguishing the "fee" from the "tax" cases insofar as the application of the "internal consistency" doctrine is concerned.

Despite the general vulnerability of unapportioned flat taxes to commerce clause challenge under the "internal consistency" principle, not every unapportioned flat tax would fail to pass muster. As noted above, ${ }^{104}$ when administrative considerations preclude the imposition of more refined levies, unapportioned flat taxes may be constitutionally tolerable. Moreover, if an unapportioned flat tax in fact constitutes a user fee imposed by the taxing authority as a charge for the use of public services or facilities, and if the fee is neither discriminatory nor excessive, it will not offend the "internal consistency" doctrine. 105

In Evansville-Vanderburgh Airport Authority District v. Delta Airlines, 106 for example, the Court sustained the authority of two municipal airports to impose flat service fees of one dollar for each passenger boarding a commercial aircraft operating from the airports. As the Court explained, the levies satisfied the requirements of nondiscrimination and reasonableness:

First, neither fee discriminates against interstate commerce and travel.

103. See Hellerstein, Hughes v. Oklahoma: The Court, the Commerce Clause, and State Control of Natural Resources, 1979 SUP. CT. REV. 51, 65 n.80.

104. See text at notes 74-75 supra.

105. See American Trucking Assns. v. Scheiner, 107 S. Ct. 2829, 2843-44 (1987).

106. 405 U.S. 707 (1972). 
While the vast majority of passengers who board flights at the airports involved are traveling interstate, both interstate and intrastate flights are subject to the same charges. Furthermore, there is no showing of any inherent difference between these two classes of flights, such that the application of the same fee to both would amount to discrimination against one or the other.

Second, these charges reflect a fair, if imperfect approximation of the use of facilities for whose benefit they are imposed. ${ }^{107}$

Even if every state (or locality) imposed such a fee, there would be no impermissible interference with interstate commerce in violation of the "internal consistency" doctrine: both interstate and intrastate passengers would pay according to their use of the facilities, and, although the facilities were used primarily by interstate passengers, the charge itself would reasonably approximate the value of the use - so interstate passengers would not be subsidizing governmental services that would be of primary benefit to local interests.

Few of the unapportioned flat taxes described above could satisfy the criteria set forth in the Evansville-Vanderburgh case. In the first place, they cannot fairly be characterized as user charges in the sense of specific charges imposed by the taxing authority for the use of publicly owned or publicly provided facilities or services. ${ }^{108}$ Moreover, even if so characterized, it would be difficult to demonstrate that the unapportioned flat taxes considered above - such as corporate qualification levies or annual business license taxes - constitute a "fair . . . approximation of the use of facilities for whose benefit they are imposed" 109 when they are not identified with the use of any particular facilities and are typically paid into the state's general fund. Furthermore, the taxes would in many instances be discriminatory in the sense that whatever "benefit" is purchased by the levy, the intrastate taxpayer would enjoy more of it than the interstate taxpayer because of its relatively greater in-state activity. ${ }^{110}$ Thus in Scheiner, the Court pointed out that the flat taxes at issue satisfied neither of the two specific conditions of nondiscrimination and reasonableness imposed by Evansville-Vanderburgh: "They discriminate against out-of-state vehicles by subjecting them to a much higher charge per mile traveled in

107. 405 U.S. at 717 (citation omitted) (emphasis in original), quoted in Scheiner, $107 \mathrm{~S}$. Ct. at $2843-44$.

108. See Commonwealth Edison Co. v. Montana, 453 U.S. 609, 621 (1981).

109. Evansville-Vanderburgh, 405 U.S. at 717.

110. This is, of course, a factual question. If it could be shown that the out-of-state business engages in no less commercial activity in the state than its intrastate competitor, the levy would not be discriminatory. One should not lose sight of the fact, however, that the Court developed the requirement that taxes must be fairly apportioned to the taxpayer's activities in the state in part because such equivalence between interstate and local commerce cannot be assumed. 
the State, and they do not even purport to approximate fairly the cost or value of the use of Pennsylvania's roads." 11

\section{Other Unapportioned Taxes}

Unapportioned flat taxes are not the only levies threatened by the "internal consistency" doctrine. Any unapportioned tax imposed on events or activities that can occur in more than one state would likewise be subject to attack under the "internal consistency" principle. For example, compensating use taxes ${ }^{112}$ imposed by states that do not grant a credit for sales or use taxes paid to other states, ${ }^{113}$ cannot withstand scrutiny under the internal consistency doctrine. Usè taxes are typically levied on "the storage, use or other consumption" of tangible personal property in the state and are measured by the sales price of the property. ${ }^{114}$ If replicated by every state, these levies would put the enterprise doing business across state lines at a competitive disadvantage to its wholly intrastate competitor.

If one views use taxes in conjunction with the sales taxes for which they compensate, the sales-use tax scheme would subject the purchase

111. Scheiner, 107 S. Ct. at 2844.

112. Compensating use taxes, which are functionally equivalent and complementary to sales taxes, see Hellerstein, Complementary Taxes, supra note 24, at 406-09, were developed to meet two problems created by the states' enactment of sales taxes. Because constitutional strictures prohibited the states from taxing sales consummated outside their borders or in interstate commerce, states feared that local merchants would lose business when prospective purchasers made out-of-state purchases to avoid sales tax liability. In addition, the states feared they would lose revenue as a result of the diversion of sales to nontaxing states. Compensating use taxes addressed these concerns by imposing a levy on the "use" in the state of tangible personal property that has not already been subjected to a sales tax in the state. The use tax is equal in amount to the sales tax that would have been imposed on the sale of the property in question if the sale had occurred within the state's taxing jurisdiction. The state overcomes the constitutional hurdle of taxing an out-of-state or interstate sale by imposing a tax on a subject within its taxing power the local "use" of property. In principle, then, the in-state consumer stands to gain nothing by making an out-of-state purchase free of sales tax because he will ultimately be saddled with an identical use tax when the property is brought into the taxing state. Use taxes discriminate on their face against interstate commerce because they apply only to goods purchased outside the state. Any in-state purchase would already have been subjected to sales tax and thus have been exempted from use tax. The Court nevertheless sustained the constitutionality of the use tax because it viewed the use tax, in conjunction with the sales tax, as imposing an equal burden on out-of-state and local purchases. See Henneford v. Silas Mason Co., 300 U.S. 577 (1937). See generally Hellerstein, Complementary Taxes, supra note 24.

113. Nevada grants no such credit. See McCray, Commerce Clause Sanctions Against Taxation on Mail Order Sales: A Re-Evaluation, 17 URB. LAW. 529, 532 n.5 (1985). Wyoming law provides for no such credit, although as a matter of administrative practice the Department of Revenue and Taxation recognizes a credit for sales taxes, but not for use taxes, paid to other states. [Wyo.] St. \& Loc. Tax Serv. [P-H] ๆ 21,362. Prior to 1988, South Carolina granted no such credit. While now permitting a credit for sales taxes paid to other states, South Carolina continues to deny credit for use taxes paid to another state. Priv. Ltr. Rul. 88-6 (S.C. Tax Commn. Feb. 10, 1988) S.C. St. Tax Rep. ๆ 200-227. See S.C. CoDE REgs. 117-174:66 (1976); S.C. CoDe ANN. \$ 12-35-815 (Supp. 1987).

114. 'See, e.g., Nev. REv. STAT. $\$ 372.185$ (1987). 
of goods in one state for use in another to two exactions - a sales tax in the state of purchase and a use tax in the state of use. The purchase of goods for local use, however, would be subjected to only a sales tax. ${ }^{115}$

If one views use taxes in isolation from sales taxes, use taxes would still subject the interstate business to the risk of multiple taxation not borne by its intrastate competitor. The interstate business using property in two or more states would pay a tax in each state in which the property was used whereas the intrastate business using the property in an identical fashion, except that it was not transported across state lines, would pay but a single tax. Under either view of the use tax, the "impermissible interference with free trade"116 is self-evident.

The overwhelming majority of states avoid any "internal consistency" objection to their use taxes by providing a credit for sales or use taxes paid to other states. ${ }^{117}$ They thus assure that the sale or use of property is in principle taxed just once whether or not it crosses state lines. ${ }^{118}$ The Supreme Court, at least up to now, has expressly refrained from holding that the states are constitutionally required to

115. One might argue that use taxes violate the commerce clause wholly apart from any "internal consistency" objection because they apply only to goods that are purchased outside the state and used within it. See note 112 supra. As noted above, however, the Court held that the apparent discrimination disappears when use taxes are considered in conjunction with sales taxes that place an equivalent burden on goods purchased locally. If states imposed two wholly independent levies on the sale and use of goods within the state, no commerce clause claim, based on "internal consistency" or other objections, could be raised to the resulting tax consequences. Purchasers of goods in one state for use in another would pay a sales tax to the state of purchase and a use tax to the state of use; purchasers of goods for local use would pay both a sales tax and a use tax to the same state.

116. Armco, Inc. v. Hardesty, 467 U.S. 638, 644 (1984).

117. See All States Tax Guide (P-H) I 256; McCray, supra note 113, at 532.

118. In practice, taxation of the use of property by more than one state can occur if states have inconsistent schemes for granting credits for use taxes paid to other states. See generally McCray, supra note 113, at 531-36. Most states impose use taxes only if the taxpayer first uses the property within their jurisdiction and grant a credit for use taxes paid to another state only if that other state was the state of first use. Id. at 533 n.7. Some states, however, impose a use tax on the use of property within their jurisdiction, even though the property was first used in another state, so long as the taxpayer has not previously paid a use tax with respect to that property to some other state. $I d$. at 533 n.8. Hence when the property is subjected to use tax in a state that follows the rule of "first collection," and that state is not the state of first use, the taxpayer will be subject to double taxation if a state in which the property was first used follows the rule of "first use" and asserts liability on that basis without allowing a credit for the tax paid to the state of subsequent use.

This is not an "internal consistency" problem, however. Both of the crediting schemes described above are "internally consistent" in the sense that, if adopted by every jurisdiction, use tax would be due to only one state - either the state of first use or the state of first collection. The problem of multiple taxation resulting from different, but internally consistent, crediting schemes is therefore analogous to the problem of multiple taxation resulting from varying, but internally consistent apportionment formulas, see text at notes 9-19 supra, and would probably not give rise to a commerce clause objection. Cf. Moorman Mfg. Co. v. Bair, 437 U.S. 267 (1978). 
grant such a credit. ${ }^{119}$ The Court's embrace of the "internal consistency" doctrine, however, may be fairly regarded as resolving the issue. ${ }^{120}$

Like use taxes that provide no credit for sales or use taxes paid to other states, New York's stock transfer tax runs into constitutional difficulties under the "internal consistency" doctrine. The levy is imposed on "all sales, or agreements to sell, or memoranda of sales and all deliveries or transfers of shares or certificates of stock"121 in any foreign or domestic corporation at a fixed rate per share, graduated according to the price of the share. The tax applies if any one of the five taxable events occurs in New York, regardless of where the rest of the transaction takes place, and if more than one taxable event occurs in the state, only one tax is payable on the entire transaction. ${ }^{122}$ If every state were to adopt such a taxing scheme, the taxpayer making an interstate trade ${ }^{123}$ would pay two or more taxes whereas a taxpayer making a wholly local trade would pay but a single tax. ${ }^{124}$ The "impermissible interference with free trade"125 under the "internal consistency" doctrine is again apparent. ${ }^{126}$

119. Williams v. Vermont, 472 U.S. 14, $21-22$ (1985); Southern Pac. Co. v. Gallagher, 306 U.S. 167, 172 (1939); Henneford v. Silas Mason Co., 300 U.S. 577, 587 (1937).

120. Justice Scalia certainly thinks it did. See Tyler Pipe Indus. v. Washington Dept. of Revenue, 107 S. Ct. 2810, 2824 (1987) (Scalia, J., dissenting). Although Professors Nowak and Rotunda have argued that the states are not required to grant a credit for sales or use taxes paid to other states against their own use taxes, Nowak \& Rotunda, Sales and Use Tax Credits, Discrimination Against Interstate Commerce, and the Useless Multiple Tax Concept, 20 U.C. DAVIS L. REV. 273 (1987), and that Armco "only superficially appears to support a multiple taxation challenge" to the failure to grant such a credit, $i d$. at 310 , their argument loses much of its force after Tyler Pipe and Scheiner. Even before the emergence of the "internal consistency" doctrine, moreover, both courts and commentators had concluded that the failure of a state to grant a credit against its use tax for sales or use taxes paid to other states would violate the commerce clause. See Montgomery Ward \& Co. v. State Bd. of Equalization, $272 \mathrm{Cal}$. App. 2d 728, $78 \mathrm{Cal}$. Rptr. 373 (1969), cert. denied, 396 U.S. 1040 (1970); McCray, supra note 113, at 564; Developments in the Law: Federal Limitations on State Taxation of Interstate Business, 75 HARv. L. REV. 953, 999-1000 (1962).

121. N.Y. TAX LAW $§ 270(1)$ (McKinney 1986).

122. N.Y. COMP. CODES R. \& REGS. tit. 20, $\$ 440.2$ (1976). York.

123. For example, a sale on the Boston Stock Exchange of shares to be delivered in New

124. Indeed, as many as five states could in principle tax the same transaction if each of the five events - the sale, the agreement to sell, the memorandum of the sale, the delivery of the shares, and the transfer of the shares (on the transfer agent's books) - were to occur in a different state. However, federal law prohibits a state from taxing a change in the beneficial or record ownership of securities merely because the transfer agent's facilities are located in the taxing state. 15 U.S.C. $\$ 78 \mathrm{bb}$ (d) (1982).

125. Armco, Inc. v. Hardesty, 467 U.S. 638, 644 (1984).

126. In 1977, the Supreme Court struck down a provision of New York's stock transfer tax that discriminated against interstate commerce by providing lower rates for certain trades made on the New York Stock Exchange. See Boston Stock Exch. v. State Tax Commn., 429 U.S. 318 (1977). These provisions were subsequently repealed. 1977 N.Y. Laws 878 . In his dissenting opinion in Tyler Pipe, Justice Scalia pointed out that the pre-1968 version of New York's stock 
One final example of an existing taxing scheme that appears to violate the "internal consistency" principle is Florida's intangible property tax. The tax is imposed at the rate of one mill $(\$ 1$ per $\$ 1,000)$ on all intangible property, except for obligations secured by Florida realty. ${ }^{127}$ As construed by the Florida courts, the tax applies to intangible property owned by taxpayers domiciled in the state, whether or not the property has acquired a business situs ${ }^{128}$ in Florida, ${ }^{129}$ as well as to intangible property owned by taxpayers domiciled outside of Florida when the property has acquired a business situs in the state. ${ }^{130}$ According to the Florida court,

[t]he taxation of accounts receivable by a state in which a corporation has acquired a business situs ${ }^{131}$ does not preclude the corporation domiciliary state from also levying an intangible tax on accounts receivable, as a corporation must pay its share of the cost of government to the sovereign from which it derives its very existence. ${ }^{132}$

Although the Florida court's statement accurately reflects the Supreme Court's reading of the due process clause, which does not prevent two states from imposing a tax upon the same intangible property, ${ }^{133}$ it is questionable whether it can survive the Court's reading of the commerce clause as expressed in the "internal consistency" principle. If every state adopted an intangible property tax that applied both to property owned by its domiciliaries and to property with a business

transfer tax, which in pertinent part resembles the existing levy, was characterized by the Court in Boston Stock Exchange as "'neutral as to in-state and out-of-state sales." " Tyler Pipe Indus. v. Washington Dept. of Revenue, 107 S. Ct. 2810, 2824 n.2 (1987) (Scalia, J., dissenting) (quoting Boston Stock Exchange, 429 U.S. at 330). Scalia went on to observe, however, that this was "plainly not true if internal consistency is a requirement of neutrality: assuming that all States had New York's pre-1968 scheme, if sale and delivery both took place in New York, there would be a single tax, while if sale took place in New York and delivery in New Jersey, there would be double taxation." $107 \mathrm{~S}$. Ct. at 2824 n.2. The problem with New York's stock transfer tax can also be viewed as a species of the multiple activities exemption considered in Armco and Tyler Pipe. Taxpayers who engage in more than one taxable activity in New York are exempt from tax on more than one taxable activity. See text at notes $212-31$ infra.

127. FLA. STAT. $\$ 199.032$ (1987).

128. Intangibles have historically been taxable at the domicile of their owner under the doctrine of mobilia sequuntur personam (movables follow the person). The Supreme Court, however, has "recognize[d] the principle that choses in action may acquire a situs for taxation other than at the domicile of their owner if they have become integral parts of some local business." Farmers Loan \& Trust Co. v. Minnesota, 280 U.S. 204, 213 (1930).

129. Florida Steel Corp. v. Dickinson, 308 So. $2 \mathrm{~d} 623$ (Fla. Dist. Ct. App.), appeal dismissed, 319 So. 2d 30 (Fla. 1975), affd., 328 So. 2d 418 (Fla. 1976).

130. Allis-Chalmers Credit Corp. v. Department of Revenue, 456 So. $2 d 899$ (Fla. Dist. Ct. App.), petition for review dismissed, 458 So. 2d 271 (Fla. 1984).

131. It is the intangible property, not the corporation, that may acquire a "business situs" apart from the domicile of its owner. See, e.g., Wheeling Steel Corp. v. Fox, 298 U.S. 193 (1936).

132. Florida Steel Corp., 308 So. 2d at 626. See also National Linen Serv. Corp. v. Thompson, 103 Ga. App. 786, 120 S.E.2d 779 (1961).

133. See State Tax Commn. v. Aldrich, 316 U.S. 174 (1942); Curry v. McCanless, 307 U.S. 357 (1939). 
situs in the state, the enterprise domiciled in one state but employing intangible property in another, where it acquires a business situs, would pay two taxes on its intangibles whereas its wholly intrastate competitor would pay but one tax. Assuming that the Court would have little difficulty in concluding that such interference with interstate capital flows affected commerce so as to warrant commerce clause scrutiny, 134 the "impermissible interference with free trade"135 under the "internal consistency" doctrine would be self-evident. ${ }^{136}$

\section{THE DEFENSIBILITY OF THE "INTERNAL CONSISTENCY" DOCTRINE}

\section{A. "Internal Consistency" and Commerce Clause Policy}

Assuming that the "internal consistency" doctrine is good law, the

134. In recent years, the Court has flatly repudiated "any suggestion that a state tax or regulation affecting interstate commerce is immune from Commerce Clause scrutiny because it attaches only to a "local' or intrastate activity." Commonwealth Edison Co. v. Montana, 453 U.S. 609, 615 (1981). In Wilson v. Department of Revenue, 302 Or. 128, 727 P.2d 614 (1986) (en banc), the court held that the commerce clause was implicated by an Oregon income tax provision limiting nonrecognition of gain upon the conversion or exchange of real property to conversions or exchanges in which the newly acquired property was situated in the state. The court declared that "[b]ecause capital investment is basic to a system of free trade, and because the framers intended to create an area of free trade under the Commerce Clause, a state law keeping investment capital, even for land, within the state can have a restrictive impact on capital markets and implicate the Commerce Clause." 302 Or. at 135, 727 P.2d at 619. See also Dominion Natl. Bank v. Olsen, 771 F.2d 108, 118 (6th Cir. 1985); Aronson v. Commonwealth, 401 Mass. 244, 248-49, 516 N.E.2d 137, 140 (1987); Blumstein, Some Intersections of the Negative Commerce Clause and the New Federalism: The Case of Discriminatory State Income Tax Treatment of Out-of-State Tax-Exempt Bonds, 31 VAND. L. REV. 473, 562 (1978).

135. Armco, Inc. v. Hardesty, 467 U.S. 638, 644 (1984).

136. The "internal consistency" doctrine likewise casts doubt upon the constitutionality of a state's taxing the entire income of domestic corporations doing business in other states while at the same time taxing an apportioned share of the income of foreign corporations doing business in the state. For many years, the view had been "widely held that the State of incorporation is free to impose a tax on the entire net income of a domestic corporation." SPECIAL SUBCOMM. on STATE TAXation OF INTERSTATE COMMERCE of the HOUSE COMM. ON THE JUdiciary, State Taxation of INTERSTATE COMMERCE, H.R. ReP. No. 1480, 88th Cong., 2d Sess. 160 (1964); see also G. AltMan \& F. KeEsling, Allocation of InCOME IN STATE TAXation 3133 (2d ed. 1950). Wholly apart from the "internal consistency" doctrine, it is open to question whether this view can survive the Court's modern opinions sustaining a state's right to tax an apportioned share of a nondomiciliary corporation's income or property while rejecting the claim that the state of the corporation's domicile had the exclusive power to tax all such income or property. Mobil Oil Corp. v. Commissioner of Taxes, 445 U.S. 425, $445-46$ (1980); Japan Line, Ltd. v. County of Los Angeles, 441 U.S. 434, $441-44$ (1979) (dictum); see Hellerstein, State Income Taxation, supra note 19, at 135-37. But see Commercial Credit Consumer Servs., Inc. v. Norberg, 518 A.2d 1336 (R.I. 1986) (sustaining over commerce clause objections state's imposition of tax on entire net income of domestic corporation carrying on substantial business outside the state). Assuming the states' power to tax their domestic corporations on their entire net income survived Mobil and Japan Line, however, the "internal consistency" doctrine would appear to bar a scheme that taxed domestic corporations on their entire income while taxing foreign corporations on an apportioned share of such income. If replicated by every state, the wholly intrastate carporation would pay tax on no more than $100 \%$ of its income whereas the corporation doing business in more than one state would pay tax on more than $100 \%$ of its income. 
question remains whether it makes good sense. As a matter of theory, it is difficult to quarrel with the proposition that the commerce clause forbids taxes that penalize taxpayers merely because they do business across state lines. ${ }^{137}$ And the "internal consistency" doctrine may be viewed as a logical corollary to that proposition. As the preceding discussion has made clear, unapportioned taxes in general, and unapportioned flat taxes in particular, can place a burden on the interstate business that is not borne by its intrastate competitor - a burden attributable solely to the fact that the interstate business plies its trade in more than one state. If the "internal consistency" doctrine functions as a mechanism for invalidating such levies - and it does, the doctrine serves a central purpose of the commerce clause.

The difficulties with the "internal consistency" doctrine lie in its problematic implications for commerce clause analysis rather than in the commerce clause policies it plainly serves. Aside from Justice Scalia's skepticism over the "theoretical underpinning for judicial 'enforcement' of the Commerce Clause,"138 no sitting Supreme Court Justice would dissent from the view that the commerce clause prohibits taxes that bear more heavily on the interstate than the intrastate enterprise merely because the former does business across state lines. Nor would there be any dispute that the "internal consistency" principle implements that view. The problem is that it arguably does more than that. As the dissenting opinions in Armco, Tyler Pipe, and Scheiner observed, ${ }^{139}$ and as the discussion in Part II of this article demonstrates, general application of the "internal consistency" doctrine undermines the authority of a number of Supreme Court precedents and places many existing state taxes in constitutional jeopardy. Perhaps this is as it should be, and the cases and taxes that have been threatened by the "internal consistency" doctrine do not deserve to survive in light of the policy that the "internal consistency" rule im-

137. See Regan, supra note 88 , at 1186.

138. Tyler Pipe Indus. v. Washington Dept. of Revenue, 107 S. Ct. 2810, 2827 (1987) (Scalia, J., dissenting). Beyond his disagreement with the Court over its application of the "internal consistency" principle in Tyler Pipe, see text at notes 34-43 \& 52 supra, Justice Scalia launched a broad-based attack on the Court's negative commerce clause jurisprudence. According to Justice Scalia, the Court in adjudicating controversies under the negative commerce clause "has engaged in an enterprise that it has been unable to justify by textual support or even coherent nontextual theory, that it was almost certainly not intended to undertake, and that it has not undertaken very well." Tyler Pipe, 107 S. Ct. at 2829 (Scalia, J., dissenting). It is worth noting that Justice Scalia spoke only for himself in expressing these views. Even Chief Justice Rehnquist, no friend of the negative commerce clause, carefully distanced himself from the portion of Justice Scalia's dissent in Tyler Pipe that questioned the constitutional basis for the Court's negative commerce clause doctrine, although the Chief Justice joined Scalia in his attack on the Court's application of the negative commerce clause to the case under consideration. $107 \mathrm{~S}$. Ct. at 2823.

139. See text at notes $28-29,34-43$ \& 52-57 supra. 
plements. On the other hand, in the face of assertions that general application of the "internal consistency" principle is "an entirely novel enterprise" 140 that would "revolutionize the law of state taxation,"141 it is worthwhile inquiring whether the Court could have faithfully effectuated its commerce clause policy by more familiar means.

\section{B. "Internal Consistency" and Multiple Taxation: Potential or Actual}

One of the principal complaints lodged against the "internal consistency" doctrine is that it measures the validity of state taxes on the basis of hypothetical rather than actual burdens on interstate commerce. By assuming that other states have adopted the challenged levy imposed by the taxing state, the "internal consistency" test may condemn the tax even though no other state has imposed a similar levy. ${ }^{142}$ As a consequence, taxes on interstate business may be struck down even though the business in fact pays no more tax than its intrastate competitor. ${ }^{143}$ This was clearly the case in Armco, where the Ohio-based manufacturer selling in West Virginia paid no manufacturing tax to Ohio; it was also true, for the most part, in Tyler Pipe, where few of the Washington manufacturers selling in other states or out-of-state manufacturers selling in Washington could point to gross receipts taxes on wholesaling or manufacturing they had paid to other states. ${ }^{144}$ Justice Rehnquist could therefore assail the "internal consistency" doctrine as rooted in "legal abstractions," 145 and he could complain that "[w] taxed, it should be unnecessary to examine a hypothetical taxing scheme to see if interstate commerce would be unduly burdened."146 Justice Scalia could likewise object that the Court, by relying on the "internal consistency" principle, was failing to adhere "to our long

140. American Trucking Assns v. Scheiner, 107 S. Ct. 2829, 2850 (1987) (O'Connor, J., dissenting).

141. Tyler Pipe, 107 S. Ct. at 2825 (Scalia, J., dissenting).

142. See text at notes $25-26$ \& note 51 supra.

143. Wholly apart from "internal consistency" concerns, the fact that the interstate business pays no more tax than its intrastate competitor does not necessarily mean that the interstate enterprise's claim is "abstract" or "hypothetical." If the interstate and intrastate business pay the same tax, but the intrastate business receives more governmental benefits for the tax, then it can be argued that the tax discriminates against interstate commerce in a very concrete way by imposing a higher effective tax rate on the interstate business. See Scheiner, $107 \mathrm{~S}$. Ct. at 2841, 2847; note 45 supra.

144. See National Can Corp. v. Washington Dept. of Revenue, 109 Wash. 2d 878, 889, 749 P.2d 1286, 1292, appeal dismissed and cert. denied, 108 S. Ct. 2030 (1988).

145. Armco, Inc. v. Hardesty, 467 U.S. 638, 647 (1984) (Rehnquist, J., dissenting) (quoting Halliburton Oil Well Cementing Co. v. Reily, 373 U.S. 64, 70 (1963)).

146. 467 U.S. at 648. 
tradition of judging State taxes on their own terms"147 and not "striking them down on the basis of assumptions as to what other States might do."148

Insofar as the "internal consistency" doctrine is designed to prevent multiple taxation of interstate business, however, the Court's "long tradition" is not precisely the one described by Justice Scalia. 149 Indeed, as originally formulated, the multiple taxation doctrine was couched in the language of possibility rather than certainty. Constitutionality depended on whether multiple burdens were capable of being imposed, not on whether they actually had been. In his seminal opinion in Western Live Stock v. Bureau of Revenue ${ }^{150}$ articulating the multiple taxation doctrine, Justice Stone observed that

[t] he vice characteristic of those [taxes] which have been held invalid is that they have placed on the commerce burdens of such a nature as to be capable, in point of substance, of being imposed with equal right by every state which the commerce touches, merely because interstate commerce is being done, so that without the protection of the commerce clause it would bear cumulative burdens not imposed on local commerce. ${ }^{151}$

In J.D. Adams Manufacturing Co. v. Storen, ${ }^{152}$ which followed on the heels of Western Live Stock, the Court declared:

The vice of the statute as applied to receipts from interstate sales is that the tax includes in its measure, without apportionment, receipts derived from activities in interstate commerce; and that the exaction is of such a character that if lawful it may in substance be laid to the fullest extent by States in which the goods are sold as well as those in which they are manufactured. Interstate commerce would thus be subjected to the risk of a double tax burden to which intrastate commerce is not exposed, and which the commerce clause forbids. ${ }^{153}$

Other opinions rendered during the formative era of the multiple taxation doctrine likewise adhered to the precept that the risk of multiple taxation sufficed to invalidate the tax and that proof of actual multiple taxation was unnecessary. ${ }^{154}$

147. Tyler Pipe Indus. v. Washington Dept. of Revenue, 107 S. Ct. 2810, 2826 (1987) (Scalia, J., dissenting).

148. $107 \mathrm{~S}$. Ct. at 2826 (emphasis in original).

149. The following discussion draws freely from Hellerstein, Construing the Uniform Division of Income for Tax Purposes Act: Reflections on the Illinois Supreme Court's Reading of the "Throwback" Rule, 45 U. CHI. L. REV. 768, 799-803 (1978) and Hellerstein, State Income Taxation, supra note 19 , at 131-35.

150. 303 U.S. 250 (1938).

151. 303 U.S. at 255-56 (citations omitted) (emphasis added).

152. 304 U.S. 307 (1938).

153. 304 U.S. at 311 (emphasis added).

154. See Michigan-Wisconsin Pipe Line Co. v. Calvert, 347 U.S. 157, 166 (1954); Ott v. Mississippi Valley Barge Line Co., 336 U.S. 169, 174 (1949); Central Greyhound Lines v. Mealy, 334 U.S. 653, 663 (1948); Joseph v. Carter \& Weekes Stevedoring Co., 330 U.S. 422, 429 (1947) 
In subsequent opinions, the Court was not as consistent as it might have been in addressing the question whether the risk of multiple taxation provided the predicate for striking down a state tax on commerce clause grounds. On a few occasions, the Court seemed to require taxpayers to demonstrate something more to support their claims. Thus in Northwestern States Portland Cement Co. v. Minnesota, ${ }^{155}$ the Court noted that "[ $\mathrm{t}]$ here is nothing to show that multiple taxation is present. We cannot deal in abstractions. In this type of case the taxpayers must show that the formula places a burden upon interstate commerce in a constitutional sense."156 And in General Motors Corp. v. Washington, ${ }^{157}$ the Court reiterated this position and noted that "[i]t has not been demonstrated what definite burden, in a constitutional sense, the St. Louis tax places on the identical shipments by which Washington measures its tax"158 or "that Oregon levies any tax on appellant's activity bearing on Washington sales." 159 Yet in other decisions rendered during the same period, the Court continued to espouse the view that the commerce clause forbade taxes that created a mere risk of multiple taxation. ${ }^{160}$

The Court's 1978 opinion in Moorman Manufacturing Co. v. Bair ${ }^{161}$ might have been read as signaling a shift in the Court's approach to the multiple taxation doctrine. In Moorman, the Court sustained the constitutionality of Iowa's single-factor sales formula for apportioning corporate income. All of the taxpayer's products sold to Iowa customers were manufactured in Illinois. The taxpayer sought

(overruled on other grounds by Department of Revenue v. Association of Washington Stevedoring Cos., 435 U.S. 734 (1978)); Gwin, White \& Prince, Inc. v. Henneford, 305 U.S. 434, 439 (1939); cf. International Harvester Co. v. Department of Treasury, 322 U.S. 340, 358 (1944) (Rutledge, J., concurring) ("either the actuality or the risk of [multiple taxation] makes the total burden cumulative, discriminatory or special"). Although Northwest Airlines v. Minnesota, 322 U.S. 292 (1944) may be regarded as inconsistent with the "risk" rule, the Court subsequently read the case narrowly so as to conform to the "risk" rule. Braniff Airways v. Nebraska State Bd. of Equalization and Assessment, 347 U.S. 590, 601-02 (1954).

155. 358 U.S. 450 (1959).

156. 358 Uं.S. at 463.

157. 377 U.S. 436 (1964) (overruled by Tyler Pipe Indus. v. Washington State Dept. of Revenue, 107 S. Ct. 2810 (1987)). See text at notes 58-67 supra (discussing the overruling of General Motors in Tyler Pipe).

158. 377 U.S. at 449.

159. 377 U.S. at 449.

160. See Standard Pressed Steel Co. v. Department of Revenue, 419 U.S. 560, 563 (1975) ("a vice in a tax on gross receipts of a corporation doing an interstate business is the risk of multiple taxation"); Evco v. Jones, 409 U.S. 91, 94 (1972) (levy subjected taxpayer to the "risk of a double tax burden"); Central R.R. v. Pennsylvania, 370 U.S. 607, 614 (1962) ("domiciliary State is precluded from imposing an ad valorem tax on any property to the extent that it could be taxed by another State, not merely on such property as is subjected to tax elsewhere") (emphasis in original).

161. 437 U.S. 267 (1978). 
to demonstrate that Iowa's single-factor formula for apportioning net income, when considered in conjunction with Illinois' three-factor formula of property, payroll, and sales, subjected income derived from its Iowa sales to the risk of duplicative taxation in violation of the commerce clause.

In rejecting this contention, the Court first declared that the taxpayer had failed to establish "the essential factual predicate for a claim of duplicative taxation," 162 i.e., it had failed to prove the portion of its income derived from Iowa sales that had in fact been taxed by both Iowa and Illinois. The Court went on to address the taxpayer's multiple taxation claim on the assumption that there had been "some overlap"163 in the taxation of the taxpayer's income. Because it was unwilling to hold that the commerce clause shielded taxpayers from multiple taxation resulting from the application of different formulas, it rejected that claim as well.

Although Moorman can be read as endorsing the view that a taxpayer must show actual multiple taxation to sustain its claim under the commerce clause, the case is more appropriately viewed as establishing the proposition that the commerce clause simply does not forbid every form of multiple taxation - whether potential or actual. To return to the point with which we commenced this article, when the risk or actuality of multiple taxation is a function of the application of two internally consistent formulas, it is constitutionally tolerable within broad limits. ${ }^{164}$

This conclusion is supported by the three decisions succeeding Moorman prior to the Court's formal embrace of the "internal consistency" principle. In its 1979 opinion in Japan Line, Ltd. v. County of Los Angeles, ${ }^{165}$ a case in which the state tax created multiple taxation in fact, the Court declared that "we have no occasion here to decide under what circumstances the mere risk of multiple taxation would invalidate a state tax."166 A year later, however, in Mobil Oil Corp. v. Commissioner of Taxes, 167 the Court squarely confronted that question. In Mobil, Vermont sought to tax an apportioned share of the taxpayer's dividend income from its unitary business being conducted

162. 437 U.S. at 276.

163. 437 U.S. at 277.

164. See text at notes 12-17 supra; Container Corp. of Am. v. Franchise Tax Bd., 463 U.S. 159, 184 (1983) (duplicative taxation of fourteen percent of taxpayer's income "within the substantial margin of error inherent in any method of attributing income among the components of a unitary business").

165. 441 U.S. 434 (1979).

166. 441 U.S. at $452 \mathrm{n} .17$ (emphasis in original).

167. 445 U.S. 425 (1980). 
in part in Vermont. Mobil maintained that Vermont's claim to an apportioned share of its dividends threatened to expose more than $100 \%$ of its income to state taxation because of the asserted power of New York, the state of Mobil's commercial domicile, to tax all of Mobil's dividends on an unapportioned basis. Since New York did not in fact tax the dividends at issue, Mobil was subjected only to a risk of multiple taxation, and the Court therefore had to face the question whether proof of actual - not merely potential - multiple taxation was a prerequisite to establishing a violation of the commerce clause.

In Mobil, the Court unequivocally put its imprimatur upon the "risk" theory of the multiple taxation doctrine. It agreed with Mobil that "the constitutionality of a Vermont tax should not depend on the vagaries of New York tax policy."168 And it rejected the state court's contention that actual multiple taxation must be demonstrated to make out a case under the commerce clause. ${ }^{169}$ A few months after its decision in Mobil, the Court reiterated its commitment to the "risk" theory of multiple taxation in Exxon Corp. v. Wisconsin Department of Revenue. ${ }^{170}$ Exxon asserted that the power of Wisconsin to tax an apportioned share of its exploration and production income subjected that income to the risk of multiple taxation because of the alleged power of the states where the exploration and production occurred to tax all of such income. As in Mobil, the Court in Exxon entertained this claim despite its explicit recognition that "it is the risk of multiple taxation that is being asserted"171 and that "actual multiple taxation has not been shown."172

In sum, the Court's "long tradition" of considering allegations of multiple taxation does reflect a willingness to consider "abstract" or "hypothetical" claims in adjudicating the validity of state taxes. The question remains, however, whether Justices Rehnquist and Scalia are right as a matter of principle in objecting to the "internal consistency" doctrine because it dispenses with the requirement that a taxpayer in fact be burdened by the tax at issue.

The Court's approach appears justified for several reasons. First, as the Court pointed out in Armco, "[a]ny other rule would mean that the constitutionality of West Virginia's tax laws would depend on the

168. 445 U.S. at 444.

169. On the merits, the Court sustained Vermont's position that it was entitled to tax an apportioned share of Mobil's foreign source dividends derived from a unitary business being conducted in part in Vermont. See generally Hellerstein, State Income Taxation, supra note 19.

170. 447 U.S. 207 (1980).

171. 447 U.S. at 228 (emphasis in original).

172. 447 U.S. at 228. 
shifting complexities of the tax codes of 49 other States, and that the validity of the taxes imposed on each taxpayer would depend on the particular other States in which it operated." ${ }^{173}$ As a matter of principle, it is undesirable to fashion a rule of law that depends for its operation on the present configuration of the statutes of other states. Second, even if acceptable as a matter of principle, it is undesirable as a matter of practice. Taxpayers would face uncertainties in determining their state tax liabilities, states would face uncertainties in predicting state tax collections, and compliance and administration difficulties would be exacerbated. Finally, even if otherwise acceptable, there is something unseemly about determining state tax liabilities "on a first-come-first-tax basis."174 Given the fundamental concerns underlying the commerce clause, it would be perverse indeed to constitutionalize a rule rewarding beggar-thy-neighbor state tax policies with state tax collections depending on who won the race to the taxpayer's door.

\section{C. "Internal Consistency" and the Fair Apportionment Criterion}

All of the taxes invalidated or imperiled by the "internal consistency" doctrine were unapportioned. Neither the business and occupation (B \& O) taxes struck down in Armco and Tyler Pipe, nor the flat highway taxes struck down in Scheiner, nor the corporate qualification, business license, and other taxes considered in Part II of this article, provided any mechanism for apportioning the tax measure to the state by reference to the taxed activities being conducted there. Yet the commerce clause has long required that a tax affecting interstate commerce be fairly apportioned to the taxpayer's activities in the taxing state. 175 Why, one may reasonably ask, did not the commerce clause's fair apportionment criterion serve to dispose of the issues in Armco, Tyler Pipe, and Scheiner, thus obviating recourse to the controversial "internal consistency" doctrine? The short answer is that it did - or at least that it should have. The longer answer, which is an extended one, may help explain why the Court ultimately invoked the "internal consistency" principle rather than the fair apportionment re-

173. Armco, Inc. v. Hardesty, 467 U.S. 638, $644-45$ (1984); see also Mobil, 445 U.S. at 444; text at note 168 supra; Austin v. New Hampshire, 420 U.S. 656, 665-66 (1975); Freeman v. Hewit, 329 U.S. 249, 256 (1946).

174. General Motors Corp. v. Washington, 377 U.S. 436, 458 (1964) (Goldberg, J., dissenting) (overruled by Tyler Pipe Indus. v. Washington Dept. of Revenue, 107 S. Ct. 2810 (1987)).

175. See Maine v. Grand Trunk Ry., 142 U.S. 217, 228 (1891); Pullman's Palace Car Co. v. Pennsylvania, 141 U.S. 18, 26 (1891); Hellerstein, State Taxation of Interstate Business: Perspectives on Two Centuries of Constitutional Adjudication, 41 TAX LAw. 37, 57 (1987). 
quirement in striking down the levies in Armco, Tyler Pipe, and American Trucking Associations.

\section{The Fair Apportionment Criterion and Gross Receipts Taxes}

It will be most fruitful to begin our discussion of this question with Tyler Pipe, which squarely confronted the fair apportionment issue. Although the Court in Tyler Pipe held that Washington's B \& O tax violated the "internal consistency" principle, 176 it nevertheless went on to consider alternative challenges to the levy because of the possibility that the legislature could take remedial action that would cure the constitutional defect the Court had identified. ${ }^{177}$ The taxpayer had argued that Washington's B \& $\mathrm{O}$ tax violated the commerce clause because it was not fairly apportioned to its activities in the taxing state. The Court's entire treatment of the issue is contained in the following paragraph:

Washington taxes the full value of receipts from in-state wholesaling or manufacturing; thus, an out-of-state manufacturer selling in Washington is subject to an unapportioned wholesale tax even though the value of the wholesale transaction is partly attributable to manufacturing activity carried on in another State that plainly has jurisdiction to tax that activity. This apportionment argument rests on the erroneous assumption that through the $\mathrm{B} \& \mathrm{O}$ tax, Washington is taxing the unitary activity of manufacturing and wholesaling. We have already determined, however, that the manufacturing tax and wholesaling tax are not compensating taxes for substantially equivalent events in invalidating the multiple activities exemption. Thus, the activity of wholesaling - whether by an in-state or out-of-state manufacturer - must be viewed as a separate activity conducted wholly within Washington that no other State has jurisdiction to $\operatorname{tax} .{ }^{178}$

The Court's disposition of the apportionment issue in Tyler Pipe cannot be squared with its professed commitment to a commerce clause jurisprudence based on the "practical effect"179 of state taxes and on "economic realities." 180 As the Court acknowledges, Washington's B \& O tax on wholesaling indisputably includes receipts attributable in part to manufacturing activity carried on in other states. Moreover, as Justice Brennan suggested in his dissent from General Motors Corp. v. Washington, ${ }^{181}$ which sustained Washington's B \& O

176. See notes 30-33 supra and accompanying text.

177. Tyler Pipe, $107 \mathrm{~S}$. Ct. at 2821. For a discussion of the Court's suggested "solution" to the levy's "internal consistency" problem, see note 33 supra.

178. $107 \mathrm{~S}$. Ct. at 2822.

179. Complete Auto Transit, Inc. v. Brady, 430 U.S. 274, 279 (1977).

180. 430 U.S. at 279.

181. 377 U.S. 436 (1964). 
tax on wholesaling over the objection that it violated the fair apportionment criterion, ${ }^{182}$

if commercial activity in more than one State results in a sale in one of them, that State may not claim as all its own the gross receipts to which the activity within its borders has contributed only a part. Such a tax must be apportioned to reflect the business activity within the taxing State. ${ }^{183}$

Indeed, it is startling to find the Court more tolerant of an unapportioned levy measured by gross receipts that "affects each transaction in proportion to its magnitude and irrespective of whether it is profitable or otherwise"184 than it would be of such a levy measured by net income that "does not arise at all unless a gain is shown over and above expenses and losses, and . . . cannot be heavy unless the profits are large."185

The Court's only response in Tyler Pipe to these arguments, other than to cite authority approving ${ }^{186}$ but not satisfactorily justifying ${ }^{187}$ unapportioned gross receipts taxes, was the bald assertion that the activity of wholesaling "must be viewed as a separate activity conducted wholly within Washington that no other State has jurisdiction to tax."188 But this view of wholesaling as a "separate activity" that a state can tax without apportionment because the activity "must be viewed" as occurring "wholly within" the jurisdiction regardless of the measure of the tax is a retreat into the very formalism that the Court had purportedly abandoned in Complete Auto Transit, Inc. v. $B r a d y^{189}$ and its progeny. The Court, after all, has told us on numerous occasions in recent years that these issues were to be decided on the basis of practical economic realities, not on the formal distinction between the subject and the measure of a tax. ${ }^{190}$ Yet in Tyler Pipe, the Court directly relied on that formal distinction - invoking the fact

182. Although the Court in Tyler Pipe overruled General Motors insofar as it sustained a levy that violated the "internal consistency" principle, see text at notes 58-67 supra, it did not discredit General Motors' disposition of the apportionment issue raised in the case.

183. General Motors, 377 U.S. at 451 (Brennan, J., dissenting).

184. United States Glue Co. v. Town of Oak Creek, 247 U.S. 321, 329 (1918); cf. Central Greyhound Lines v. Mealey, 334 U.S. 653, 663 (1948) ("tax may constitutionally be sustained on the [gross] receipts from the transportation apportioned as to the mileage within the State").

185. United States Glue Co., 247 U.S. at 329.

186. Tyler Pipe, 107 S. Ct. at 2822 (citing Moorman Mfg. Co. v. Bair, 437 U.S. 267, 280-81 (1978) and Standard Pressed Steel Co. v. Department of Revenue, 419 U.S. 560, 564 (1975)). infra.

187. See Hellerstein, Interstate Business, supra note 77, at $168-76$ and text at notes 189-206

188. Tyler Pipe, 107 S. Ct. at 2822.

189. 430 U.S. 274 (1977).

190. See, e.g., Commonwealth Edison Co. v. Montana, 453 U.S. 609, 614-17 (1981); Department of Revenue v. Association of Washington Stevedoring Cos., 435 U.S. 734, 743-48 (1978); Complete Auto Transit, 430 U.S. at 280-81. 
that the subject of the tax is local wholesaling - to avoid an inquiry into the propriety of the measure of the tax, which concededly includes out-of-state values.

The critical point is that a tax levied upon interstate activity whether measured by gross receipts, net income, or other values must reflect the portion of the enterprise's activity that is being conducted in the taxing state, and the tax measure must be adjusted accordingly. Otherwise the state, under the guise of taxing some "local incident" of that interstate activity, would be able to sweep into its tax base gross receipts, net income, or other values that other states could include in their tax bases with equal justification by identifying some other "local incident" of that interstate activity. ${ }^{191}$ The risk of multiple taxation to which such a regime would expose interstate commerce is plain.

The Court has generally recognized this problem in the context of taxes on interstate business activity measured by net income, property, and other values, and it has therefore required apportionment of those values to reflect the taxpayer's activity in the taxing state, regardless of whether the formal subject of the tax was some local privilege or event. The question is why has it not done so in the context of taxes on interstate business activity measured by gross receipts? The answer, as I have explained at greater length elsewhere, ${ }^{192}$ seems to lie in two considerations.

First, with respect to gross receipts taxes on interstate sales activity, the Court has analogized gross receipts taxes to retail sales and use taxes. ${ }^{193}$ Because retail sales and use taxes are consumer taxes which are separately stated, collected from purchasers, and imposed on a transaction-by-transaction basis, apportionment of such levies - in the sense of division of the tax base - has never been viewed as a practicable solution to the multiple taxation issues that such taxes raise. ${ }^{194}$ Instead, the Court in effect has had to decide whether the

191. See generally Strecker, "Local Incidents" of Interstate Business, 18 OHro ST. L.J. 69 (1957). This is not to suggest that states may never impose unapportioned taxes on "local" subjects without burdening interstate commerce. They may do so if the tax base has no multistate attributes over which other states may properly assert their taxing authority. Hence there is no need to apportion an ad valorem tax on real property nor a gross receipts tax on a local massage parlor. But a tax measured by values generated by interstate activity is not immune from the requirement of fair apportionment merely because it is framed as a tax on a distinctly "local" event such as the privilege of engaging in local business.

192. Hellerstein, Interstate Business, supra note 77, at 168-76. The ensuing discussion draws freely from this article.

193. International Harvester Co. v. Department of Treasury, 322 U.S. 340, 348 (1944).

194. Barrett, "Substance" vs. "Form" in the Application of the Commerce Clause to State Taxation, 101 U. PA. L. REv. 740, 755, 776 (1953); Kust \& Sale, State Taxation of Interstate Sales, 46 VA. L. REV. 1290, 1323-24 (1960). 
state from which the goods were sent, the state to which the goods were shipped, or both, or neither would be permitted to tax retail interstate sales. ${ }^{195}$ In fact, the Court has generally allowed the state of destination to tax retail sales transactions while forbidding the state of origin from doing so. ${ }^{196}$ By analogy, the Court has generally sustained gross receipts taxes on interstate sales activity when imposed by the state to which the goods were shipped ${ }^{197}$ while prohibiting such taxes when imposed by the state from which the goods were sent. ${ }^{198}$

Second, with respect to gross receipts taxes in general, the Court for many years espoused the view that the states could impose excise taxes on manufacturing, producing, and extracting activities measured by the unapportioned gross receipts from those activities. ${ }^{199}$ The Court considered these activities to be "local" in nature, and it permitted the states to measure the value of the activities by the gross receipts they generated notwithstanding their intimate connection with interstate activities.

The Court's failure to insist on an analytically sound apportionment solution in Tyler Pipe may thus be attributable to the existence of two large bodies of supporting precedent that it saw no compelling reason to disturb. Plausible explanations, however, must be distinguished from reasoned justifications. As suggested above, ${ }^{200}$ there is no theoretical justification for the Court's disposition of the apportionment issue in Tyler Pipe. Moreover, even the precedents that appear at first glance to support the result in Tyler Pipe lose much of their force upon closer examination. The cases that eschew apportionment as an impractical (or unworkable) solution to the multiple taxation issues raised by retail sales taxes have little bearing on the question whether general business taxes imposed on interstate sales activity are apportionable. Unlike retail sales taxes, general business gross receipts taxes are neither separately stated nor imposed on a transaction-by-

195. See International Harvester, 322 U.S. at 358-62 (Rutledge, J., concurring and dissenting).

196. See Hellerstein, Interstate Business, supra note 77, at 172.

197. See Standard Pressed Steel Co. v. Department of Revenue, 419 U.S. 560 (1975); General Motors Corp. v. Washington, 377 U.S. 436 (1964) (overruled by Tyler Pipe Indus. v. Washington State Dept. of Revenue, 107 S. Ct. 2810 (1987)); Field Enterprises v. Washington, 352 U.S. 806 (1956) (per curiam), affg., 47 Wash. 2d 852, 289 P.2d 1010 (1955); International Harvester, 322 U.S. at 340; Allied Mills, Inc. v. Department of Treasury, 318 U.S. 740 (1943) (per curiam), affg., 220 Ind. 340, 42 N.E.2d 34 (1942).

198. See Evco v. Jones, 409 U.S. 91 (1972); Gwin, White \& Prince, Inc. v. Henneford, 305 U.S. 434 (1939); J.D. Adams Mfg. Co. v. Storen, 304 U.S. 307 (1938).

199. See, e.g., American Mfg. Co. v. City of St. Louis, 250 U.S. 459 (1919) (manufacturing); Heisler v. Thomas Colliery Co., 260 U.S. 245 (1922) (extracting); Hope Natural Gas Co. v. Hall, 274 U.S. 284 (1927) (producing).

200. See text at notes 179-92 supra. 
transaction basis. Hence, the analogy the Court may have drawn between retail sales taxes and general business gross receipts taxes on interstate sales activity is a false one insofar as the apportionment question is concerned. Furthermore, the Court indicated in its 1981 opinion, Commonwealth Edison Co. v. Montana, ${ }^{201}$ that its earlier precedents sustaining unapportioned gross receipts taxes on "local" activities may no longer be good law. ${ }^{202}$ The Court made it clear, at least as a matter of principle, that gross receipts taxes affecting interstate commerce were subject to the same "consistent and rational method of inquiry" "203 it had applied to other taxes which focused on " 'the practical effect of a challenged tax." "204 This " 'practical' analysis"205 requires, among other things, that a tax affecting interstate commerce be "fairly apportioned."206

\section{Applying the Fair Apportionment Criterion to the Court's "Internal Consistency" Cases}

If the Court in Tyler Pipe had approached the apportionment issue along the lines suggested by Justice Brennan's dissent in General Motors, ${ }^{207}$ it would not only have met the objections set forth in the foregoing discussion, but it would also have resolved the multiple taxation problem raised by Tyler Pipe without recourse to the "internal consistency" doctrine. An example demonstrates this is so.

Assume that there are three taxpayers, $A, B$, and $C$, each of which

201. 453 U.S. 609 (1981).

202. In Commonwealth Edison, which involved a commerce clause challenge to Montana's severance tax, the Court explicitly disapproved the rationale of Heisler and its progeny (including Hope Natural Gas) that taxes on "local" activities were not subject to commerce clause scrutiny. 453 U.S. at 614-17. On the other hand, the Court approved the statement of the Montana Supreme Court that there was no question in the case involving multiple taxation because " "the severance can occur in no other state' and "no other state can tax the severance." " 453 U.S. at 617.

203. 453 U.S. at 615 (quoting Mobil Oil Corp. v. Commissioner of Taxes, 445 U.S. 425,443 (1980)).

204. 453 U.S. at 615.

205. 453 U.S. at 616 .

206. Complete Auto Transit, Inc. v. Brady, 430 U.S. 274, 279 (1977) (quoted in Commonwealth Edison, 453 U.S. at 617). See also Shores, State Taxation of Interstate Commerce - Quiet Revolution or Much Ado About Nothing?, 38 TAx L. REv. 127, 150 (1982) (arguing for application of apportionment principles to gross receipts taxes); Miers, The "Urban Severance Tax": Some Questions as to Apportionment, 18 TULSA L.J. 359, 390 (1983) (suggesting apportionment of severance taxes); $c f$. National Liberty Life Ins. Co. v. State, 62 Wis. 2d 347, 215 N.W.2d 26 (1974), appeal dismissed and cert. denied, 421 U.S. 940, 946 (1975) (tax on gross premiums of insurance company struck down under due process clause because it was unapportioned); Indiana Dept. of Revenue v. P.F. Goodrich Corp., 260 Ind. 41, 292 N.E.2d 247 (1973) (gross income tax could not be applied to proceeds of a liquidation dividend received from an out-of-state corporation unless it was fairly apportioned).

207. See text at note 183 supra. 
has $\$ 100$ of gross receipts from the wholesale sale of products it manufactures. Taxpayer $A$ is an interstate business that manufactures products in Washington that it sells in other states, and its Washington apportionment percentage, based on its average percentage of Washington property, payroll, and sales, is $67 \% .{ }^{208}$ Taxpayer $B$ is an interstate business that manufactures products in other states that it sells in Washington, and its Washington apportionment percentage, based on the same factors, is $33 \%$. Taxpayer $C$ is an intrastate business that manufactures products in Washington that it sells in Washington, and it has no right to apportion its income because its activities are wholly intrastate. ${ }^{209}$

If Washington's gross receipts tax had been applied on an apportioned basis to Taxpayers $A, B$, and $C$, there would have been no discrimination against interstate commerce and no possibility of multiple taxation (beyond that which the Court has found tolerable under the commerce clause). ${ }^{210}$ Taxpayer $A$ would have paid a manufacturing tax on $67 \%$ of its gross receipts, the proportion that fairly reflected its business activities in the state. Taxpayer $B$ would have paid a wholesaling tax on $33 \%$ of its gross receipts, the proportion that fairly reflected its business activities in the state. Taxpayer $C$ would have paid a wholesaling tax on $100 \%$ of its gross receipts, the proportion that fairly reflected its business activities in the state. The multiple activities exemption would be unobjectionable because it would simply relieve $C$, the local manufacturer/wholesaler, from paying a tax on $200 \%$ of its gross receipts from its commercial activity in the state. Moreover, insofar as Taxpayers $A$ or $B$ engaged in both manufacturing and wholesaling activity in the state, they too would benefit from the multiple activities exemption which would assure that no more than $100 \%$ of the receipts from the activities fairly apportioned to the state are taxed by the state.

In taxing only an apportioned share of the gross receipts from interstate manufacturing-wholesaling activity, Washington would thus avoid creating an unconstitutional risk of multiple taxation. Other states would likewise be free to tax a fairly apportioned share of the gross receipts from interstate manufacturing-wholesaling activity attributable to activities in such states. These levies would be justified under long-standing commerce clause doctrine sustaining apportioned

208. See note 19 supra.

209. A taxpayer engaged in business in only one state has no right to apportion his tax base. See J. Hellerstein \& W. Hellerstein, supra note 13, at 422.

210. See text at notes 14-17 supra. 
taxes on interstate commercial activities without reference to their "internal consistency."

Furthermore, even if the "internal consistency" requirement was applied to apportioned gross receipts taxes, it would be satisfied by the formulas typically employed for apportioning net income. ${ }^{211}$ Nor would the multiple activities exemption in Washington's (and in West Virginia's) B \& O tax raise any question of "internal consistency." The apportionment of the tax measure - gross receipts - would insure that only a fair share of the tax base was being attributed to the state, and the multiple activities exemption would serve the salutary function of assuring that the same tax measure was not taxed twice to the same taxpayer merely because the legislature had included it in the tax base under two taxable subjects - manufacturing and wholesaling. 212

Just as apportionment would provide a solution to the multiple tax problem raised by Armco and Tyler Pipe without recourse to the "internal consistency" doctrine, so apportionment would provide a solution to the multiple tax problem raised by Scheiner without recourse to the "internal consistency" doctrine. If the axle and marker fees had been apportioned to the truck's activity in the state on the basis of instate miles to total miles or some other factor, the levies would have created no commerce clause problem. Interstate trucks would have paid only that portion of the fee that corresponded to the proportion of their activity in Pennsylvania, and interstate commerce would have suffered no discrimination or multiple tax burden. Moreover, as in the case of apportioned gross receipts taxes, apportioned flat truck taxes would satisfy the "internal consistency" requirement. If every state imposed Pennsylvania's flat highway taxes, but apportioned them to the mileage that the truck operated in the state, the interstate truck would pay no more than the intrastate truck, although it would make its payment to several jurisdictions.

In short, the commerce clause concerns of discrimination and multiple tax burdens that the Court addressed with the aid of the "internal consistency" principle in Armco, Tyler Pipe, and Scheiner could as easily have been dealt with by a rigorous application of traditional apportionment principles without mention of the phrase "internal consistency." The Court's unwillingness to take seriously its own re-

211. See Container Corp. of America v. Franchise Tax Bd., 463 U.S. 159, 169-71 (1983); text at notes 9-19 supra.

212. See Judson \& Duffy, An Opportunity Missed: Armco, Inc. v. Hardesty, A Retreat from Economic Reality in Analysis of State Taxes, 87 W. VA. L. REV. 723, 744-46 (1985) (criticizing the Court's analysis of gross receipts taxes in Armco as "artificial" and arguing that the Court should have required apportionment of the tax base). 
quirement that taxes be fairly apportioned may have created an environment in which some proxy for the fair apportionment criterion like "internal consistency" - would be invoked for the same purpose.

If a proper application of the fair apportionment requirement would have invalidated the levies at issue in Armco, Tyler Pipe, and Scheiner, it raises the question whether the Court's adoption of the "internal consistency" principle makes any difference, except a semantic one. Insofar as the Court has refused in the past to insist on true apportionment in cases like Armco, Tyler Pipe, and Scheiner, the application of the "internal consistency" rule does indeed make a significant difference in the outcomes of such cases and of others considered in Part II. From a theoretical standpoint, however, it would appear that an uncompromising application of the fair apportionment requirement to cases involving allegations of multiple taxation would in most instances produce results essentially indistinguishable from the application of the "internal consistency" principle. This conclusion should not be surprising considering that the fair apportionment requirement and the "internal consistency" requirement are both designed, at least in part, ${ }^{213}$ to prohibit the same evil - multiple taxation of the interstate business. Perhaps, then, the "internal consistency" doctrine is not so "novel"214 or "revolutionary"215 after all, but is merely another name for the fair apportionment requirement the Court should have been insisting on all along.

There is, however, at least one multiple tax problem that escapes solution under the "internal consistency" principle but is addressed by a strict application of the fair apportionment requirement. As Justice Scalia observed in his dissenting opinion in Tyler Pipe, although the "internal consistency" principle condemns taxes if the adoption of the same tax by other states would impose a multiple tax burden on the multistate business, it does not deal with the problem of multiple taxation created by states imposing different taxes on the interstate enterprise. ${ }^{216}$ Thus, as the "simplest example" of a valid, but cumulatively burdensome levy, he points out that

[a] tax on manufacturing (without a tax on wholesaling) will have a discriminatory effect upon interstate commerce if another State adopts a tax on wholesaling (without a tax on manufacturing) - for then a company manufacturing and selling in the former State would pay only a single tax, while a company manufacturing in the former [S]tate but selling in

213. The concerns of the fair apportionment requirement are not limited to multiple taxation. See text at notes $245-63$ infra.

214. See text at note 140 supra.

215. See text at note 141 supra.

216. Tyler Pipe, 107 S. Ct. at 2826 (Scalia, J., dissenting). 
the latter State would pay two taxes. ${ }^{217}$

Justice Scalia regarded this as further evidence of the ill-considered nature of the "internal consistency" doctrine because he saw "no reason why the fact that other States, by adopting a similar tax, might cause Washington's tax to have a discriminatory effect on interstate commerce, is of any more significance than the fact that other States, by adopting a dissimilar tax, might produce such a result."218

Because Justice Scalia shared the Court's view that apportionment was an inappropriate solution to the problem raised by Washington's B \& O tax, ${ }^{219}$ he did not consider the possibility that apportionment of Washington's tax would solve the multiple tax problem he identified. As suggested above, ${ }^{220}$ a requirement that gross receipts taxes be apportioned would have assured that an interstate manufacturer/wholesaler's receipts would be divided between the manufacturing and selling jurisdictions based on its activities in the state. The fact that one state taxed the receipts under a manufacturing tax while the other taxed them under a wholesaling tax would have no effect on the enterprise's tax liability. Thus, the problem identified by Justice Scalia would disappear. ${ }^{221}$

217. 107 S. Ct. at 2826.

218. 107 S. Ct. at 2826 (emphasis in original). United Engrs. \& Constructors v. Rose, 363 S.E.2d 477 (W. Va. 1987) illustrates Justice Scalia's point. The taxpayer performed engineering and design services outside of West Virginia in connection with a construction contract performed within West Virginia. The Court held, as a matter of state law, that all of the receipts from the construction contract, which included payment for the engineering and design services, were taxable under West Virginia's B \& O tax as receipts from "contracting" performed in the state. The court then turned to the taxpayer's claim that the West Virginia tax violated the "internal consistency" requirement because the same engineering and design services taxed by West Virginia would allegedly be taxed by the state where the services were performed, assuming, as "internal consistency" analysis requires, that the other state taxed "contracting" services. On this assumption, the interstate contractor would be taxed twice on its engineering and design services whereas its intrastate competitor would be taxed just once. The court rejected this argument on the ground West Virginia taxes design and engineering services only where the construction is being conducted, and that if every state adhered to such a scheme there would be no multiple taxation in violation of the "internal consistency" requirement. 363 S.E.2d at 482-83. If, however, another state imposed a "professional services" tax measured by receipts from all professional services performed in the state regardless of where the services were ultimately used, while West Virginia imposed a "contracting" tax measured by receipts from all contracts for local construction regardless of where the services underlying the contract were performed, the interstate enterprise would suffer a multiple tax burden on its receipts from engineering and design services, even though its "internal consistency" claim would fall on deaf ears. Apportionment of the receipts from engineering and design services performed as a part of interstate commercial activity, on the other hand, would protect the interstate enterprise from a multiple tax burden not borne by its local competitor. See text at notes 207-12 supra.

219. Tyler Pipe, $107 \mathrm{~S}$. Ct. at 2824-25; see text at note 40 supra.

220. See text at notes 207-12 supra.

221. Wholly apart from the possibility of apportionment as a solution to the problem Justice Scalia has identified, one may question whether he has in fact identified a problem of discrimination under the commerce clause. It is true, as Justice Scalia points out, that if different states employ different taxing schemes, some interstate firms will pay more tax than their intrastate 
The foregoing discussion of the multiple activities exemption issues raised by Armco and Tyler Pipe has proceeded on the assumption that, with respect to manufacturing and wholesaling conducted by a single taxpayer, the West Virginia and Washington B \& $O$ taxes were in substance a single levy applied to a single tax base; ${ }^{222}$ that the multiple activities exemption was designed to avoid taxing the same taxpayer twice for engaging in closely related business activity; that the tax was in no sense a value added tax imposed on separately identified gross receipts representing manufacturing value, on the one hand, and wholesaling value, on the other; and that essentially the same gross receipts were included in the tax measure whether the levy was denominated a "manufacturing" tax or a "wholesaling" tax. This view of the B \& $\mathrm{O}$ taxes generally reflects their actual operation. ${ }^{223}$

This view is not, however, the only one that may be taken of the matter. If one adopts a more formalistic approach to the levies, as did the Court in Armco and Tyler Pipe, and considers the tax on manufac-

competitors. However, interstate firms are not disadvantaged as such. Under Justice Scalia's hypothetical, an interstate firm that manufactured in the state that taxes wholesaling and wholesaled in the state that taxes manufacturing would pay no taxes at all, and would thus enjoy an advantage over its intrastate competitors in either state. Hence any disadvantage to the particular interstate firm from the two different taxing schemes would be adventitious. As noted above, the Court has found such adventitious burdens resulting from states' different taxing schemes constitutionally tolerable. See text at notes 14-17 and 161-64 supra. These adventitious burdens should be distinguished from the predictable burdens imposed on the interstate enterprise as such as a result of the multiple activities exemptions at issue in Armco and Tyler Pipe. See text at notes 222-31 infra.

222. Nothing in this or the preceding discussion should be read as suggesting that the state must impose a single tax on manufacturing and wholesaling activity conducted by a single taxpayer. The discussion simply assumes that this is the way West Virginia and Washington were in fact taxing manufacturer/wholesalers. As noted below, other assumptions are plausible, and they require that the issues be analyzed within an analytical framework different from that constructed above.

223. Thus the measure of West Virginia's (subsequently repealed) tax on manufacturing was "the value of the entire product manufactured," W. VA. CODE § 11-13-2b (Supp. 1983) (repealed 1985), which was generally determined by "the gross proceeds of sales." W. Va. Business and Occupation Tax Regulation § 2.02(a), [Pre-July 1, 1987 Transfer Binder] [W. Va.] St. Tax Rep. (CCH) I 68-810 (Dec. 29, 1982); the measure of West Virginia's tax on wholesaling was "the gross income of the business," W. VA. CODE $§ 11-13-2 c$ (1974) (repealed 1985), which meant the "gross receipts of the taxpayer derived from ... . sales and the value proceeding or accruing from the sale of tangible property ..."W. VA. CODE $\S 11-13-1$ (1987). The measure of Washington's tax on manufacturing was "the value of the products," WASH. REV. CODE ANN. $\$ 82.04 .240$ (Supp. 1988), which was generally determined by the "gross proceeds of sales." WASH. ADMIN. CODE 458-20-112 (1983); the measure of Washington's tax on wholesaling was the "gross proceeds of sales." WASH. REV. CODE ANN. $\$ 82.04 .270$ (Supp. 1988). In short, the measure of both the manufacturing and wholesaling taxes in West Virginia and Washington was generally gross proceeds or receipts from sales, although the measure of the manufacturing tax on out-ofstate sales could be reduced to reflect out-of-state transportation costs. W. Va. Business and Occupation Tax Regulation § 2.03(b), [Pre-July 1, 1987 Transfer Binder] [W. Va.] St. Tax Rep. (CCH) I 68-810 (Dec. 29, 1982); WASH. ADMIN. CODE § 458-20-112 (1983). All this may simply attest to the fact that manufacturers typically generate gross receipts by selling at wholesale. 
turing and the tax on wholesaling as two separate exactions on discrete activities, even when carried on by the same taxpayer, ${ }^{224}$ then the preceding analysis of the multiple. activities exemption problem, with its emphasis on apportionment as the proposed solution, is not wholly satisfactory. If the manufacturing and wholesaling taxes are perceived as two independent levies, a multiple activities exemption could discriminate against interstate commerce despite the fact that both taxes are fairly apportioned. Because the exemption from a fairly apportioned gross receipts tax on manufacturing would be available to the taxpayer only insofar as it had fairly apportioned receipts from wholesaling, and because exemption from a fairly apportioned gross receipts tax on wholesaling would be available to the taxpayer only insofar as it had fairly apportioned receipts from manufacturing, the multiple activities exemption would create an incentive for the taxpayer to conduct its manufacturing activities where it conducted its wholesaling activities. $^{225}$

The vice of such a scheme was recognized by the Supreme Court in Maryland v. Louisiana, ${ }^{226}$ where it struck down a tax on Outer Continental Shelf (OCS) gas used in Louisiana because, among other things, the tax could be credited against Louisiana severance tax liability: "The obvious economic effect of this Severance Tax Credit is to encourage natural gas owners involved in the production of OCS gas to invest in mineral exploration and development within Louisiana rather than to invest in further OCS development or in production in other States."227 The levy therefore violated the commerce clause principle forbidding state taxing measures that "foreclos[e] tax-neutral deci-

224. When manufacturing and wholesaling activities are conducted by different taxpayers, the B \& O levies clearly tax the two activities separately. It is only when manufacturing and wholesaling activities are conducted by a single taxpayer that one can argue that the $B \& O$ tax effectively subjects the activities to a single levy. The multiple activities exemption therefore discriminates in favor of vertically integrated enterprises, which will pay only one tax on manufacturing or wholesaling, and against independent manufacturers and wholesalers which will collectively pay two such taxes. But such discrimination does not implicate commerce clause concerns. See Exxon v. Maryland, 437 U.S. 117 (1978) (sustaining, over commerce clause objections, regulation discriminating against vertically integrated oil companies).

225. For example, assume that every state imposed a fairly apportioned gross receipts tax on both manufacturing and wholesaling activity conducted within the state, with an exemption from the manufacturing tax insofar as the gross receipts were taxable under the wholesaling tax. Only those taxpayers who conducted all their manufacturing and wholesaling activities in a single state, or who conducted their manufacturing activities in precise proportion to their wholesaling activities in particular states, would enjoy the full benefit of the exemption. Taxpayers whose wholesaling activities did not precisely correspond on a geographical basis to their manufacturing activities would lose the benefit of the exemption insofar as taxable receipts from wholesaling were unavailable to reduce the gross receipts taxable under the manufacturing tax.

226. 451 U.S. 725 (1981).

227. 451 U.S. at 757. 
sions" 228 by "providing a direct commercial advantage to local business"229 and thereby inducing taxpayers to conduct in-state activities. ${ }^{230}$

More fundamentally, the problem with the multiple activities exemption, viewed in the context of two separate exactions imposed on two independent taxable activities, is that it provides relief from the tax on one activity based on the carrying on in the state of the other. Such a scheme creates an incentive for taxpayers to consolidate their activities in a single state so as to minimize their aggregate tax burden, at least if one assumes, along with "internal consistency" analysis, that every state has adopted a similar taxing regime. However, apportionment does not completely solve this problem. Apportionment addresses the problem of over taxation that arises when a state seeks to tax more than its appropriate share of a tax base to which other states may lay a legitimate claim. It does not address the problem of under taxation that arises when a state relinquishes its claim to its usual share of a tax base because the taxpayer engages in additional local activity.

Apportionment therefore may be regarded as less than a panacea to the multiple activities exemption problem if one views the manufacturing and wholesaling taxes imposed on taxpayers engaged in both activities as two distinct levies. Such a conclusion, however, does not ipso facto justify the Court's invocation of the "internal consistency" principle to invalidate the exemptions. When the effect of a state levy is to "undertax" local activity vis-a-vis interstate commerce, the Court's commerce clause precedents provide ample authority to invalidate such taxes without recourse to the "internal consistency" principle. ${ }^{231}$

\section{3. "Internal Consistency," Fair Apportionment, and Tax Credits}

A final piece in the "internal consistency" mosaic that warrants brief attention is the impact of tax credits on the constitutional analysis. A tax that appears to be internally inconsistent will nevertheless

228. Boston Stock Exch. v. State Tax Commn., 429 U.S. 318, 331 (1977).

229. Northwestern States Portland Cement Co. v. Minnesota, 358 U.S. 450, 458 (1959).

230. See, e.g., Westinghouse Elec. Corp. v. Tully, 466 U.S. 388 (1984) (invalidating tax credit that induced taxpayers to conduct export-related activity within state); Halliburton Oil Well Cementing Co. v. Reily, 373 U.S. 64 (1963) (invalidating sales-use tax scheme that induced taxpayers to assemble equipment within state).

231. See, e.g., Westinghouse, 466 U.S. at 400 ("undertaxation" of those engaged in local export-related activity where larger tax credit was provided for shipping activities conducted in New York); Boston Stock Exchange, 429 U.S. at 331 ("undertaxation" of those selling stock in New York state). 
pass the "internal consistency" test if the taxing state grants a credit for taxes paid to other states on the same tax base. For example, a flat highway tax, though internally inconsistent on its face, will pass the "internal consistency" test if the taxing state grants a credit for flat highway taxes imposed by other states. If such a taxing scheme were in force in every state, the interstate trucker, like his intrastate competitor, would pay a tax to only one state, and he would receive a credit against that tax in other states in which he operated. ${ }^{232}$ The crediting device thus shields the interstate business from the risk of multiple taxation that the "internal consistency" doctrine was designed to prevent. ${ }^{233}$

The Supreme Court explicitly recognized this point in Tyler Pipe. It observed that Washington could eliminate the interstate enterprise's exposure to multiple taxation of receipts generated by wholesaling and manufacturing by granting local manufacturers a credit against Washington manufacturing tax liability for wholesale taxes paid to other states and by granting out-of-state manufacturers a credit against Washington wholesaling tax liability for manufacturing taxes paid to other states. ${ }^{234}$ A similar point can be made with regard to the credit that most states provide against their use taxes for sales or use taxes paid to other states. ${ }^{235}$ Citing Tyler Pipe, the Supreme Court of Illinois in Goldberg v. Johnson ${ }^{236}$ likewise declared that the provision of a credit against the state's telecommunications excise tax "cures any possible constitutional infirmity resulting from multiple taxation."237

If a credit against state tax liability for taxes paid to other states on the same tax base generally eliminates the risk of multiple taxation, and with it the claim of internal inconsistency, the question remains

232. This assumes that every state has imposed a flat tax of the same magnitude and that the states have employed consistent rules for allowing credits against other states' taxes. Although this assumption is appropriate for purposes of "internal consistency" analysis, which contemplates the replication of the challenged state's tax by other states, as a practical matter states' flat highway taxes will vary in amount and differing crediting schemes can produce multiple taxation of the interstate business. See note 118 supra.

233. Although true as a matter of principle, inconsistent crediting schemes can in practice result in multiple taxation. See note 118 supra.

234. Tyler Pipe, $107 \mathrm{~S}$. Ct. at 2819-21; see note 33 supra. The Court made an analogous point in Scheiner with regard to registration fees. Because every state recognizes the registration of every other state, the payment of a registration fee to one state - even though flat and unapportioned - does not impose a multiple tax burden on the interstate truck: "Having paid one registration fee, a vehicle may pass among the States as freely as it may roam the State in which it is based ...." $107 \mathrm{~S}$. Ct. at 2840 . In substance, the registration reciprocity provisions operate like credits.

235. See text at notes 117-20 supra.

236. 117 Ill. 2d 493, 512 N.E.2d 1262 (1987) (per curiam), prob. juris. noted sub nom. Goldberg v. Sweet, $108 \mathrm{~S}$. Ct. 1010 (1988). The case is considered further at notes 251-63 infra.

237. Goldberg, 512 N.E.2d at 1267. 
whether a credit similarly disposes of objections to a levy on fair apportionment grounds. The Vermont Supreme Court gave an affirmative answer to this question in sustaining a use tax measured by the full, unapportioned purchase price of a corporate aircraft, even though only $17 \%$ of the aircraft's flight time was attributable to Vermont. ${ }^{238}$ In response to the taxpayer's claim that the use tax had to be apportioned to the aircraft's activities in Vermont, the court declared:

Two methods of taxation have been developed to ameliorate the risk of cumulative tax burdens upon interstate transactions. First, . . multiple taxation may be avoided by a tax credit which provides an offset or exemption if a sales or use tax has been paid to another state or jurisdiction. Second, the tax burden may be apportioned. . . .

...

The Commerce Clause does not require apportionment in addition to a tax credit. The rule of Complete Auto [Transit, Inc. v. Brady ${ }^{239}$ ] requiring a tax on interstate commerce to be "fairly apportioned" is satisfied here. The state has provided a tax credit in lieu of apportionment. This credit, not unlike a proportionate tax, eliminates the possibility of cumulative use tax liability. 240

Opinions from other state tribunals share the Vermont court's view that the availability of a credit against other states' taxes obviates the need for apportionment. ${ }^{241}$ Moreover, the Supreme Court has recently remarked in passing that a credit satisfies the fair apportionment requirement: "The Louisiana taxing scheme is fairly apportioned, for it provides a credit against its use tax for sales taxes that have been paid in other States."242

The problem with the position advanced by the Vermont court is not that it reached the wrong result in the case before it. As noted above, ${ }^{243}$ apportionment of the tax base has never been regarded as a practicable solution to the multiple taxation issues raised by retail sales and use taxes like the levy at issue in the Vermont and kindred

238. Frank W. Whitcomb Constr. Corp. v. Commissioner of Taxes, 144 Vt. 466, 479 A.2d 164 (1984).

239. 430 U.S. 274 (1977).

240. Whitcomb Construction, 144 Vt. at $471,473,479$ A.2d at 167-68.

241. Director of Revenue v. Superior Aircraft Leasing Co., 734 S.W.2d 504, 507 (Mo. 1987); KSS Transp. Corp. v. Baldwin, 9 N.J. Tax 273, 287 (1987); H.K. Porter Co. v. Commonwealth, 534 A.2d 169, 171 (Pa. Commw. Ct.1987).

242. D.H. Holmes Co. v. McNamara, 108 S. Ct. 1619, 1623 (1988). In Holmes, the Court upheld, over commerce clause objections, the application of Louisiana's use tax to a retailer's customers in the state. The Court's comment regarding apportionment, in general, and the relationship between apportionment and credits, in particular, was dictum because the taxpayer raised no issue of unfair apportionment in the case. See Brief for Appellant, D. H. Holmes Co. v. McNamara, 108 S. Ct. 1619 (1988) (No. 87-267).

243. See text at notes $194-99$ supra. 
cases. $^{244}$ In such cases, a crediting scheme may be the only feasible method of avoiding multiple taxation. Insistence on true apportionment, in the sense of division of the tax base among the states that have a substantial connection with the interstate activity that generates the tax base, could create administrative chaos in the enforcement of retail sales and use taxes.

The problem with the position advanced by the Vermont court is rather that it equates the fair apportionment requirement with the proscription against multiple taxation when in fact the fair apportionment requirement is not so confined. To be sure, the fair apportionment requirement precludes multiple taxation within certain limits, ${ }^{245}$ and tax credits achieve the same objective. But our acceptance of tax credits as a practical solution to the multiple tax problems raised by sales and use taxes should not blind us to the fact that an unapportioned tax remains an unapportioned tax regardless of whether it is offset by a credit.

Retail sales and use taxes are generally unapportioned. ${ }^{246}$ There is no more justification in principle for a state taxing the unapportioned gross receipts from an interstate retail sale - i.e., a sale of goods shipped from a seller in one state to a purchaser in another - than there is for a state taxing the unapportioned gross receipts from other interstate business activity. ${ }^{247}$ In both cases "commercial activity in more than one State results in a sale in one of them," 248 and there is no reason why the state of origin or the state of destination may "claim as all its own the gross receipts to which the activity within its borders has contributed only a part."249 In relying on credits as a remedy to

244. All the cases cited in note 241 supra involved retail use taxes on corporate aircraft. See also Service Merchandise Co. v. Jackson, 735 S.W.2d 443, 445 (Tenn. 1987); Great Am. Airways v. Nevada State Tax Commissioner, 101 Nev. 422, 426-28, 705 P.2d 654, 657-58 (1985) (per curiam), cert. denied, 107 S. Ct. 74 (1986) and Miller v. Commissioner of Revenue, 359 N.W.2d 620, 622 (Minn.), cert. denied, 471 U.S. 1116 (1985), where the courts indicated that retail use taxes need not be apportioned.

245. See text at notes 12-17 supra.

246. Some states apportion retail sales and use taxes imposed on purchases of vehicles and parts by interstate transportation companies. See FLA. STAT. $\$ \S 212.08(8)-.08(9)$ (1987); MINN. STAT. ANN. § 297A.212 (West Supp. 1988).

247. See text at notes 175-206 supra for the argument that states should be required to apportion gross receipts on interstate business activity.

248. General Motors Corp. v. Washington, 377 U.S. 436, 451 (1964) (Brennan, J., dissenting).

249. General Motors, 377 U.S. at 451; see also International Harvester Co. v. Department of Treasury, 322 U.S. 340, 358-62 (1944) (Rutledge, J., concurring) (undue burden of cumulative taxation exists in the absence of a credit or apportionment). It is true that Justice Brennan, before penning the words quoted in the text, did declare that "[o]f course, when a sale may be localized completely in one State, there is no danger of multiple taxation, and, as in the case of a retail sales tax, the State may use as its tax base the total gross receipts arising within its borders." General Motors, 377 U.S. at 450. Moreover, this view that there are wholly "local" events 
the multiple taxation problem raised by unapportioned sales and use taxes, it should be noted that the grant of a credit does not make the tax fairly apportioned and that credits are no more than a second-best alternative, compelled by administrative considerations, to the fair apportionmnent of a tax base.

The reason why it is important not to confuse a credit with the apportionment of a tax base is that the fair apportionment requirement is directed at broader concerns. Wholly apart from its role in preventing multiple taxation, the fair apportionment criterion serves to limit the territorial reach of state power by requiring that the state's tax base corresponds to the taxpayer's in-state presence. ${ }^{250} \mathrm{~A}$ credit designed to avoid the risk of multiple taxation may not satisfy the fair apportionment requirement - at least in cases in which apportionment is administratively practicable.

This distinction is well illustrated by Goldberg $v$. Johnson, to which this article alluded briefly above ${ }^{251}$ and in which the Supreme Court has noted probable jurisdiction. ${ }^{252}$ Goldberg involved a commerce clause challenge to Illinois' telecommunications excise tax, which is imposed on the "act or privilege of originating or receiving interstate telecommunications" in the state at the rate of five percent of the unapportioned gross charge for such telecommunications. ${ }^{253}$ Although the levy appeared on its face to flunk the "internal consistency" test, ${ }^{254}$ the Illinois Supreme Court, as noted above, held that

that may be taxed without apportionment is one to which the Court still adheres, at least in part. Tyler Pipe Indus. v. Washington Dept. of Revenue, 107 S. Ct. 2810, 2822 (1987); Commonwealth Edison Co. v. Montana, 453 U.S. 609, 616 (1981). See also text at note 178 and note 202 supra. As a matter of logic, however, the statement quoted in the text is as pertinent to a tax on an interstate retail sale as to a tax on business activity measured by receipts from interstate wholesale sales. Unless we are to be mesmerized by the labels to which the states attach to exactions measured by receipts from interstate activities - and we have it on high authority that we should not, see, e.g., Complete Auto Transit, Inc. v. Brady, 430 U.S. 274 (1977), there is no reason in theory why the two levies considered by Justice Brennan should be treated differently for purposes of the fair apportionment criterion.

250. Norfolk \& W. Ry. v. Missouri State Tax Commn., 390 U.S. 317, 323-25 (1968). This aspect of the fair apportionment requirement is rooted in both the commerce and due process clauses. 390 U.S. at $325 \&$ n.5. See also note 11 supra.

251. See text at note 236 supra.

252. Goldberg v. Johnson, 117 Ill. 2d 493, 512 N.E.2d 1262 (1987), prob. juris. noted sub. nom. Goldberg v. Sweet, 108 S. Ct. 1010 (1988).

253. Ill. REV. STAT. ch. 120, para. 2004, (1985), quoted in Goldberg, 512 N.E.2d at 1265 (emphasis omitted).

254. In fact, the "internal consistency" issue was more complex than the provision quoted in the text suggests. The tax only applied if the call was "charged to the taxpayer's service address" in Illinois. ILL. REV. STAT. ch. 120, para. 2002(b) (1985). Hence one could argue that the tax was "internally consistent": if every state imposed such a tax, the interstate call would be taxed no more than once - in the state of the taxpayer's service address. The Illinois court nevertheless found that the tax created "a real risk of multiple taxation ... [because] at least two taxing jurisdictions levy a tax similar to the instant tax . . . in Illinois." Goldberg, 512 N.E.2d at 1267. 
the availability of a credit against telecommunications taxes paid to other states cured this apparent infirmity in the statute. ${ }^{255}$

The fact that the availability of a credit may prevent multiple taxation, however, does not resolve the question of fair apportionment. Unless one regards the fact that Illinois taxes only calls that are charged to an Illinois service address ${ }^{256}$ as a form of apportionment an argument that even the Illinois Supreme Court did not advance, ${ }^{257}$ it is difficult to contend that Illinois' telecommunications excise tax is fairly apportioned to the commercial activity that generates the gross receipts Illinois seeks to tax. Such activity is quintessentially interstate - the transmission of telephone signals across state lines - and the receipts it generates reflect activity both in Illinois and in other states. Yet Illinois "claim[s] as all its own the gross receipts to which the activity within its borders has contributed only a part."258 Insofar as the Illinois Supreme Court sought to justify the levy on the ground that it was imposed on a local "taxable event,"259 it smacks of the formalism that the Court has discarded and replaced with a commerce clause jurisprudence rooted in practical economic reality. ${ }^{260}$ And insofar as the Illinois court sought to justify the levy on the ground that the credit precluded multiple taxation, ${ }^{261}$ its argument was essentially a non-sequitur that fails to respond to the underlying claim of unfair apportionment.

There may well be a case to be made for the Illinois Supreme Court's refusal to confront the apportionment issue, apart from an invocation of Supreme Court precedents such as Tyler Pipe that likewise fail to dispose of the fair apportionment issue in an analytically defensible manner. ${ }^{262}$ Conceivably, apportionment of Illinois' telecommunications excise tax is no more feasible as a practical matter than apportionment of retail sales and use taxes. If this were true, then failure to require true apportionment, and reliance on the credit as a means of avoiding multiple taxation, may be an acceptable bow to the

The Court's reliance on the crediting provision of the tax as an answer to the multiple taxation claim, see text at note 237 supra, implies that it did not believe the levy was "internally consistent" without the credit.

255. Goldberg, 512 N.E.2d at 1267; see text at note 237 supra.

256. See note 254 supra.

257. Goldberg, 512 N.E.2d at 1266 ("it is not an apportioned tax").

258. General Motors Corp. v. Washington, 377 U.S. 436, 451 (1964) (Brennan, J., dissenting).

259. Goldberg, 512 N.E.2d at 1266.

260. See text at notes 201-06 supra. But see note 249 supra.

261. 512 N.E.2d at 1267.

262. See text at notes 176-206 supra. 
same administrative considerations that underlie the commerce clause principles governing retail sales and use taxes. This is not an argument on which the Illinois Supreme Court relied, however, in reaching its conclusion. Nor is it one that is particularly persuasive in light of the fact that other states apportion their taxes on interstate telecommunications. ${ }^{263}$

\section{CONCLUSION}

We come finally to the question to which the title of this article seems to promise a response - is "internal consistency" foolish? The answer is "no," at least in terms of the fundamental commerce clause policy underlying the "internal consistency" principle, namely, that interstate business should not be subject to additional tax burdens merely because it engages in commercial activity across state lines. On the other hand, the Court did not need to invoke the doctrine of "internal consistency" in striking down the unapportioned levies in Armco, Tyler Pipe, and Scheiner. It could have invalidated them under a straightforward application of the venerable fair apportionment requirement. Had it taken this course, it might have "clear[ed] up the tangled underbrush of past cases"264 and made a positive contribution to the Court's modern commerce clause jurisprudence. Instead, the Court has embraced a doctrine of "internal consistency" that may introduce confusion and uncertainty in an area of the law that has had more than its fair share of both.

263. See, e.g., FLA. STAT. § 212.05(1)(e)2c (1987); N.M. STAT. ANN. § 7-9-56(C) (1986) (effective through July 1, 1988); VA. CoDE § 58.1-2623 (Supp. 1988) (repealed effective 1990 tax year). In any event, the Supreme Court will provide us with the final word on these and other issues raised by Goldberg when it renders its decision in the case during its October 1988 Term.

264. Spector Motor Serv. v. O'Connor, 340 U.S. 602, 612 (1951) (Clark, J., dissenting). 